\title{
Spatial distribution and sources of tsunami deposits in a narrow valley setting - insight from 2011 Tohoku-oki tsunami deposits in northeastern Japan
}

Tomoya Abe ${ }^{1 *}\left(\mathbb{D}\right.$, Kazuhisa Goto ${ }^{2,3}$ and Daisuke Sugawara ${ }^{2,4}$

\begin{abstract}
Sedimentary processes and spatial distributions of tsunami deposits in valleys have poorly been understood despite many paleo-tsunami deposits have recently been discovered from sedimentary sequences in valleys. We conducted an exhaustive investigation of 2011 Tohoku-oki tsunami deposits in a narrow valley at the south end of Sendai Plain, northeastern Japan, to collect sedimentological data of the tsunami deposits in the valley and to correlate them with tsunami inundation and associated sedimentary processes. The tsunami deposits were investigated at 174 sites to cover the entire inundation area of the narrow valley. We analyzed thickness, sedimentary structures, and grain size of the tsunami deposits to correlate their spatial variation with tsunami flow hydrodynamics and topographic features. The tsunami deposits, composed of sand and mud layers, were found to be $0-40 \mathrm{~cm}$ thick. Sand thickness generally decreased inland with local fluctuation. The sand layer was mostly composed of single unit on the upper main valley and sub-valleys, although it was mainly composed of 2-6 sub-units on the lower main valley and in the pond. Mud thickness is strongly controlled by local sources, namely, the rice paddy and the pond. The depositional area of the mud layer coincides with the distribution of the rice paddies and the pond location. The mud layer also considerably thicker in and around the pond. These results indicate that sediment thickness and sedimentary structures are highly varied on a local scale, but they are generally controlled by local topography. Sediment budget in the valley was estimated, and it may provide implications to general sedimentary process. Total depositional volume of the tsunami sand deposited on land is half of the volume of sediments disappeared from the sandy beach and sand dune, suggesting the rest must have been discharged into the sea by the backwash. Spatial distribution of sediment thickness and sedimentary structures as well as sedimentary processes inferred from 2011 Tohoku-oki tsunami deposits will benefit searching and identification of paleo-tsunami deposits in valleys of other coastal environments.
\end{abstract}

Keywords: 2011 Tohoku-oki tsunami, Narrow valley setting, Tsunami deposit, Spatial distribution, Sedimentary processes, Sediment budget

\footnotetext{
* Correspondence: tomoya-abe@aist.go.jp

${ }^{1}$ Geological Survey of Japan, National Institute of Advanced Industrial

Science and Technology (AIST), 1-1-1 Higashi, Tsukuba, Ibaraki 305-8567,

Japan

Full list of author information is available at the end of the article
} 


\section{Introduction}

Tsunami deposits are useful for estimating recurrence intervals and magnitudes of past tsunami waves (Goff et al. 2012). Ancient tsunami events have been elucidated since the 1980s using paleo-tsunami deposits (Atwater 1987; Dawson et al. 1988; Minoura and Nakaya 1991). Nevertheless, identification criteria and sedimentological characteristics of tsunami deposits were not well understood (Shanmugam 2012). Case studies of recent tsunami effects have proven to be extremely useful for understanding the sedimentary processes that occur during tsunami flow and for refining the criteria used to identify paleo-tsunami deposits in the geological record (Weiss and Bourgeois 2012). Therefore, many field observations were conducted soon after recent tsunamis, especially after the 1990s (e.g., Shi et al. 1995; Gelfenbaum and Jaffe 2003).

Many studies of recent tsunami events have clarified sedimentological characteristics of tsunami deposits. For instance, tsunami deposits generally become thinner and finer inland (Peters and Jaffe 2010). However, the thickness, grain size, and sedimentary structures of tsunami deposits fluctuate locally under the influence of hydraulic characteristics, topography, and sediment sources (e.g., Hori et al. 2007; Paris et al. 2007; Moore et al. 2011). Most studies of recent tsunami deposits, especially of the 2011 Tohoku-oki tsunami, were conducted at low-lying coastal plains, where tsunami inundation might have been generally unrestricted by topography (e.g., Goto et al. 2011; Abe et al. 2012; Richmond et al. 2012; Szczuciński et al. 2012; Takashimizu et al. 2012). The tsunami deposits left by recent tsunamis in lowlying coastal plains generally exhibit landward thinning and fining trends (e.g., Gelfenbaum and Jaffe 2003; Hori et al. 2007; Fujino et al. 2010; Szczuciński et al. 2012). In contrast, studies of recent tsunami deposits in valleys, where tsunami inundation can be restricted by topography, are rare (Apotsos et al. 2011; Naruse et al. 2012; Putra et al. 2013; Yamada et al. 2014; Goto et al. 2017). These works have reported some characteristics of tsunami deposit in valleys as follows. Apotsos et al. (2011) inferred that onshore transport and deposition of tsunami deposits were limited by the availability of sediment supply and a steep slope. Naruse et al. (2012) evaluated onshore tsunami deposits as sourced not only from eroded beach sands but also from the seafloor judged from on rough estimation of erosional and depositional volumes by the tsunami and occurrence of ostracod assemblages in the tsunami deposit. Yamada et al. (2014) demonstrated that sudden deceleration of the tsunami flow velocity, constrained by the local topography, caused rapid deposition of tsunami boulders and of layered sandy to gravelly tsunami deposits. Putra et al. (2013) argued that tsunami flow forms onshore deposits that become finer and thinner landward and showed that they were laterally variable, being thinner in the topographic lows than in the surrounding higher areas. Goto et al. (2017) described transportation of eroded clasts back toward the valley bottom as associated with the return flow along a channel. These observations imply that source and transport processes in valleys possibly differ from those found on low-lying coastal plains. From the above, the distribution pattern and sedimentary process in a valley are surely more complicated than those on a low-lying coastal plain. It is possible that these sedimentological characteristics greatly differ among landform types. Recent geological studies of tsunami deposits have specifically emphasized low-lying coastal plains rather than valleys. Some reasons might explain that dominant preference: (1) Emergency surveys after tsunami events have a time constraint related to post-disaster recovery processes. (2) Tsunami deposits in low-lying coastal plain present advantages for comparison with numerical simulations and flume experiments. (3) Sedimentary processes on low-lying coastal plains are easier to understand than those taking place in valleys. In fact, on lowlying coastal plains, observations along shore-normal transects are an effective strategy to investigate tsunami inundation and associated sedimentary processes. Because surveys of recent tsunami events in valleys have been few for the reasons described above, sedimentary processes and spatial characteristics of tsunami deposit in valleys still have remained poorly understood.

Earlier studies of tsunami deposits have typically been conducted along shore-normal transects (e.g., Gelfenbaum and Jaffe 2003; Hori et al. 2007; Moore et al. 2011; Takashimizu et al. 2012). Actually, spatial surveys are rare (Paris et al. 2007; Choowong et al. 2008; Naruse et al. 2012) because distribution patterns of tsunami deposits are presumed to have a dominant shore-normal trend. This assumption is probably valid for low-lying coastal plains in cases where the tsunami inundation occurs in a direction perpendicular to the shoreline. By contrast, tsunami flow and sedimentary processes in valleys can be complex because of topographic constraints. Field observations along shore-normal transects might be insufficient to characterize tsunami inundation and sedimentation occurring in valleys.

Before the 2011 tsunami, paleo-tsunami deposits on low-lying coastal plains had been well studied (e.g., Atwater 1987; Minoura and Nakaya 1991). To enhance capabilities of finding suitable places for paleo-tsunami research, valleys should be regarded as target areas. In fact, after the 2011 tsunami, reports of paleo-tsunami deposits in valleys have also increased (e.g., Goto et al. 2015, 2019; Ishimura and Miyauchi 2015; Inoue et al. 2017; Fujino et al. 2018; Kusumoto et al. 2018; Shimada et al. 2019), although recent examples of tsunami 
deposits in valleys, which can be a reference of interpreting paleo-tsunami deposits, still have been very few. Regarding this point, improved understanding of sedimentary processes and spatial distribution of recent tsunami deposit in valleys is crucially important for paleo-tsunami deposit research.

The main objective of this study is to examine spatial distributions and sedimentary processes of 2011 Tohoku-oki tsunami deposits in a valley setting using exhaustive field observation and analyses of grain size distributions and diatom assemblages. Furthermore, we estimated the sediment budget between depositional and erosional volumes based on a spatial thickness distribution and comparison of pre-tsunami and post-tsunami aerial photographs and high-resolution digital elevation models (DEM), to illustrate general sedimentary process occurred in a valley.

\section{Study area}

Deposits of the 2011 Tohoku tsunami were surveyed in a narrow valley of Yamamoto Town, Miyagi Prefecture, northeastern Japan. The area is situated at the southern end of Sendai Plain (Fig. 1a). The valley is surrounded by hills of greater than $15 \mathrm{~m}$ height, comprising Pliocene sandstone (Fig. 1b, Additional file 2: Fig. S1). The $2.3 \mathrm{~km}$ long main valley stretches roughly east-west, with subvalleys developed in a nearly orthogonal direction to the main valley with lengths ranging $10-100 \mathrm{~m}$. The land use before the 2011 tsunami is characterized by (1) a 0 $80 \mathrm{~m}$ wide sandy beach (Fig. 2a), (2) 30-100 m wide coastal forests (black pine trees) on $2-3 \mathrm{~m}$ high sand dunes, and (3) a $2 \mathrm{~km}$ wide wetland for rice paddies. The $6.2 \mathrm{~m}$ high seawalls were constructed at the boundary between back beach and sand dune before the 2011 tsunami. These seawalls were mostly broken by the tsunami. A small coastal pond, named Suijin-numa ( $90 \mathrm{~m}$ long, $200 \mathrm{~m}$ width, less than $3 \mathrm{~m}$ depth) (Fig. 2b), is placed in lowland at $0.7-0.9 \mathrm{~km}$ from the shoreline. Paleo-tsunami deposits such as those formed by the 869 Jogan and the 1611 Keicho tsunami were found earlier from the pond sediment (Sawai et al. 2008). Besides, Shinozaki et al. (2015) reported that considerable bottom erosion (approx. $1.4 \mathrm{~m}$ thick) took place in this lake by the 2011 tsunami.

Matsumoto (1981) revealed that the post-glacial sea level rose from 8 to $5 \mathrm{ka}$ and that it reached close to the present sea level at around $5 \mathrm{ka}$; the alluvial lowland migrated seaward during the last $5 \mathrm{ka}$ with stabilization of the relative sea level in Sendai Plain. Processes of sediment transport and deposition can vary between the alluvial lowland and other portions of the valley, due to the difference in the sloping. Based on analysis of aerial photographs and DEM, topographic boundary between flatter alluvial lowlands and steeper hill slopes in the valley was interpreted as around $3 \mathrm{~m}$ above Tokyo Peil (T.P.) (Fig. 1c).

The landform types of the study area were divided into the lower main valley $(<$ T.P. $3 \mathrm{~m}$ ), upper main valley (> T.P. $3 \mathrm{~m}$ ), north sub-valley (> T.P. $3 \mathrm{~m}$ ), south sub-valley (> T.P. $3 \mathrm{~m}$ ), pond, sand dune, and sandy beach (Fig. 1c). Furthermore, we subdivided sub-valley areas into N1N4 and S1-S3 (Fig. 1c).

\section{Methods/experimental}

\section{Field survey}

Field surveys were mostly conducted in July, October, and November in 2012, with additional works conducted in April 2013 and December 2014 (Table 1). We investigated 2011 tsunami deposits at 174 survey sites (land, 162 sites; pond, 12 sites) at $10-100 \mathrm{~m}$ spacing in the valley (Fig. 1b) to elucidate spatial variation, sedimentary processes, and sediment budget of the tsunami deposit. We conducted pit surveys with less than $1 \mathrm{~m}$ depth on land areas and coring with $1 \mathrm{~m}$ depth using a Russian Peat Borer on shipboard for pond areas. We observed thickness, grain size, and sedimentary structures (normal grading, inverse grading, lamination, mud (rip-up) clasts, mud drape, and the number of sand sub-units) of the tsunami deposit at each site to clarify their spatial characteristics. We conducted additional survey for taking beach sand sample (sampling site is shown in Fig. 1c) for grain size analysis in December 2014.

We also observed soil erosion at the base of the tsunami deposit to estimate the erosion volume. According to interviews with local farmers, the pre-tsunami thickness of rice paddy soil was approximately $0.2 \mathrm{~m}$ in this area. We assumed that this is the typical thickness of paddy soil. We observed the thickness of the remaining soil beneath the tsunami deposit. Besides, we identified the numbers of sub-units in the sand layer judged from existence of the mud drape or an internal erosional boundary within sand layers and abrupt change in grain size and mineral composition within the sand layers.

The tsunami flow height at the shrine, called MizuShrine, placed at the center of the valley (Fig. 1b), was measured by using Differential Global Positioning System (DGPS) survey equipment and hand-held laser rangefinders (Impulse 200; Laser Technology Inc.) in July, 2012. The run-up height at the inundation limit in the valley head (Fig. 2c) was estimated using DEM with grid size $2 \mathrm{~m}$. The flow heights and run-up heights measured by the 2011 Tohoku Earthquake Tsunami Joint Survey Group (TETJSG; Mori et al. 2012) were used as supplemental data (Fig. 1b). The pond depth was measured using a portable sounder (Hondex PS-7; Honda Electronics Co. Ltd.). Based on visual observations of the tsunami deposits, the deposits in the study area were classified into three types: a sand layer covered by a mud 


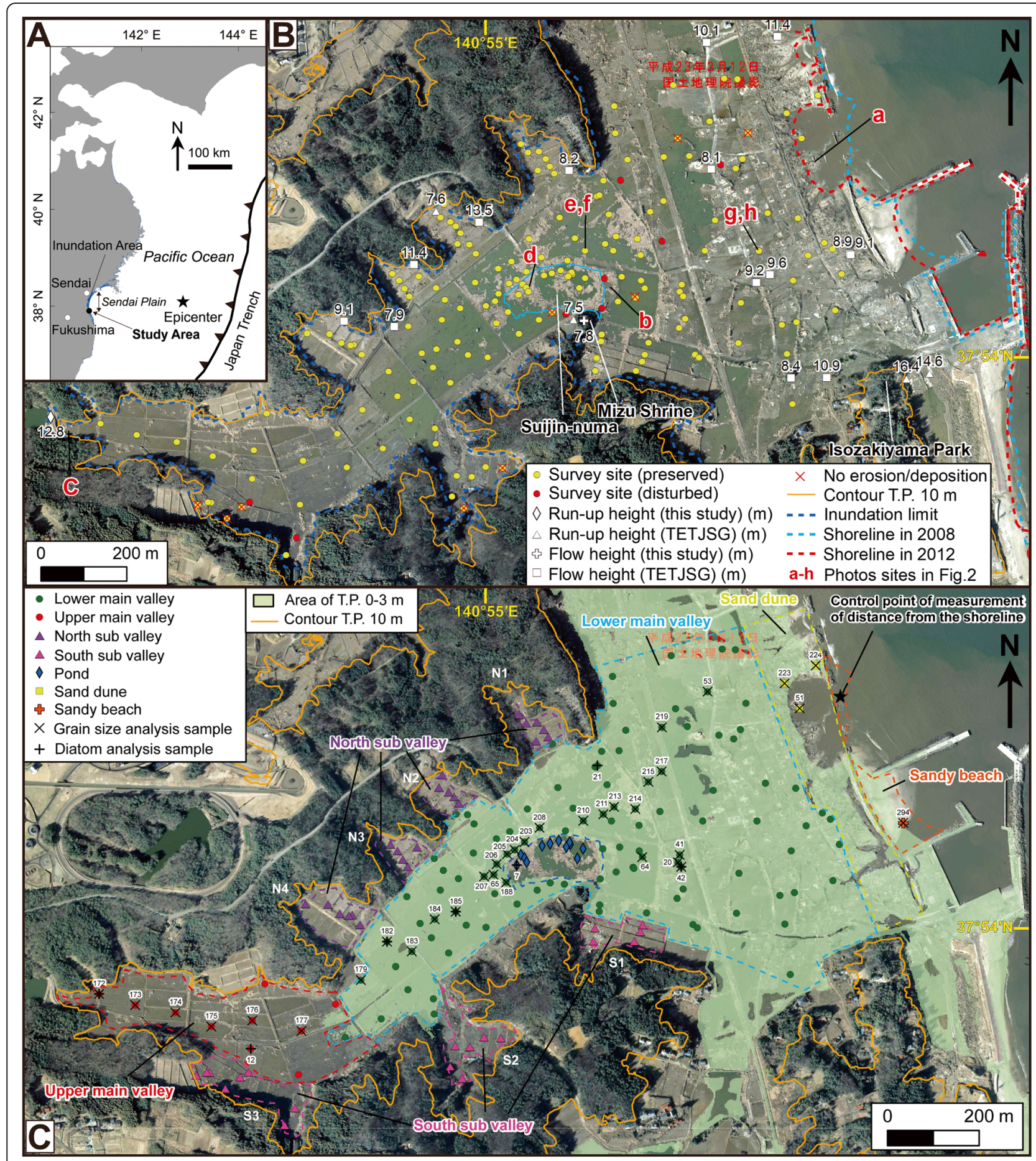

Fig. 1 Maps showing a the location of study area; $\mathbf{b}$ survey site, run-up height, flow height, inundation limit, and location of photograph sites in Fig. 2; and c topographic type and sampling site for analysis. a The inundation area of the 2011 tsunami is based on data provided by the Geospatial Information Authority of Japan (GSI). b, c The aerial photographs taken on the day after the tsunami (March 12, 2011) and the shoreline location were provided by GSI. Inundation limit, run-up height, and flow height were measured for this study and by the 2011 Tohoku Earthquake Tsunami Joint Survey Group (TETJSG). c The contour line is based on the $2 \mathrm{~m}$ grid digital elevation model (DEM) data after the tsunami provided by GSI. No erosion/deposition means that no erosion of pre-existing sediments or no deposition caused by the 2011 tsunami 

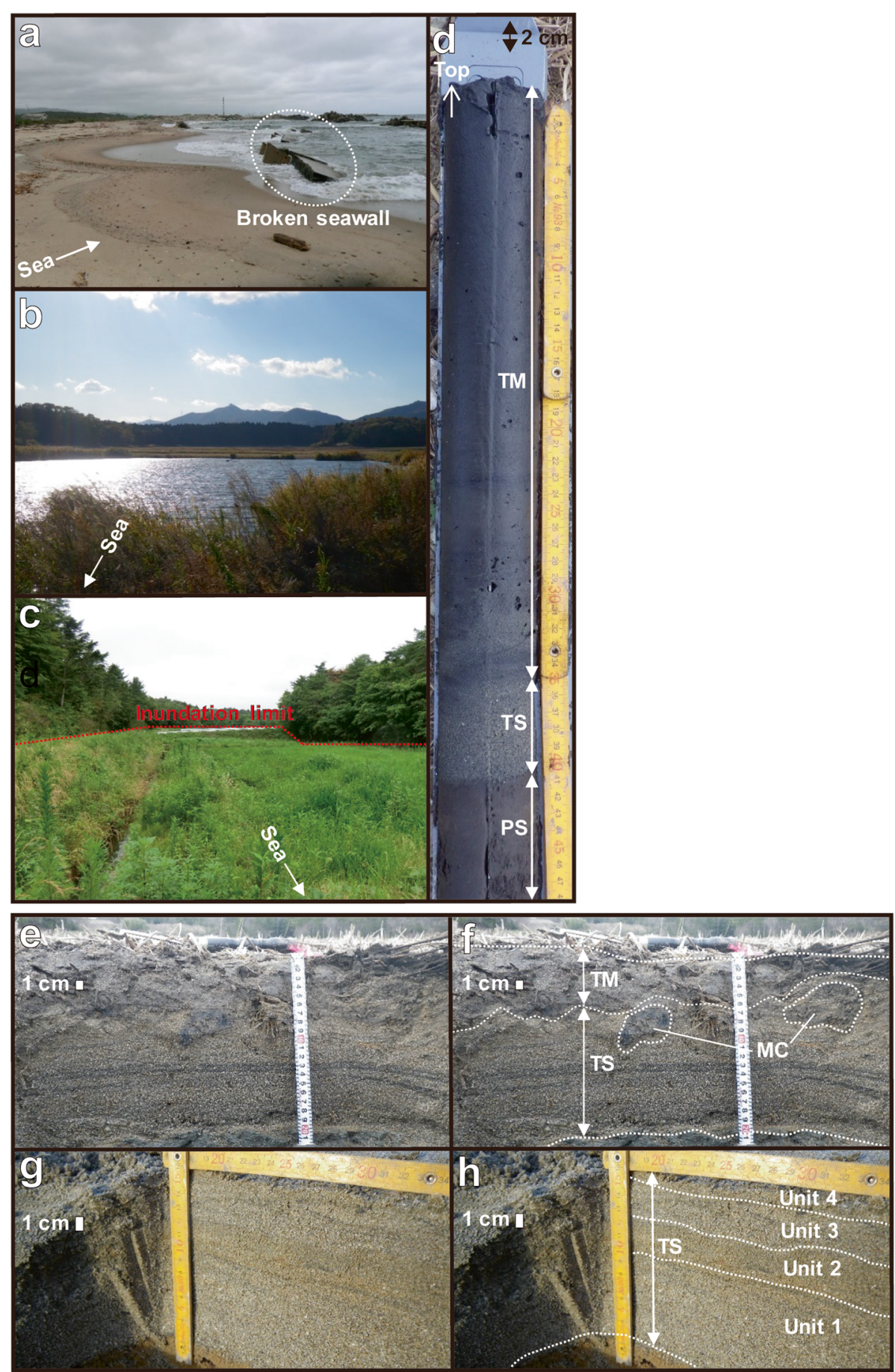

Fig. 2 Photographs taken in the study area. a Beach eroded and seawall broken by the 2011 tsunami (July 19, 2012). b Pond (Suijin-numa) (November 21, 2012). c Inundation limit at valley head in the upper main valley (July 18, 2012). d Tsunami sand layer covered with tsunami mud layer in the pond (April 11, 2013). Photograph sites are portrayed in Fig. 1b. TS, tsunami sand layer; TM, tsunami mud layer; PS, pond sediment. e, f Tsunami sand layer covered with tsunami mud layer (April 11, 2013). g, h Tsunami sand layer with four sub-units (April 11, 2013). e, g Raw photos. $\mathbf{f}, \mathbf{h}$ Photos with interpretation of the structure of the tsunami deposit. Photograph sites are portrayed in Fig. 1b. TS, tsunami sand layer; TM, tsunami mud layer; MC, mud clasts 
Table 1 List of survey dates and number of survey sites during each period

\begin{tabular}{ll}
\hline Survey month & Number of survey sites \\
\hline July 2012 & 37 \\
October 2012 & 52 \\
November 2012 & 74 \\
April 2013 & 11 \\
December 2014 & 1 \\
\hline
\end{tabular}

layer (Fig. 2d-f), a sand layer without an overlying mud layer (Fig. $2 \mathrm{~g}, \mathrm{~h}$ ), and a mud layer without an underlying sand layer.

\section{Grain size distribution}

Sandy deposit samples were collected at 48 sites in the valley (beach sand, 1 site; sand dune, 3 sites; tsunami deposit, 43 sites; Fig. 1c). Respective units and sub-units of the sand layers were sampled separately for grain size analyses to identify the sand source and to reveal landward change of grain size distribution. Before analysis, organic matter was removed using hydrogen peroxide. Sieving was performed to separate sediments finer than $63 \mu \mathrm{m}(4 \mathrm{phi})$ and coarser than $2 \mathrm{~mm}(-1 \mathrm{phi})$. We used a settling tube for analysis of grain size distribution of sandy sediments ranging from 4 to -1 phi. We calculated the average of median grain size and grain size sorting at each sampling site. The average calculation is weighted by using a weighting coefficient of the thickness. Grain size data were compared with existing data of the grain size distribution of the seafloor sands sampled from the offshore sea bottom (12-23 m depth) off the coast of the valley (Ohshima et al. 1986).

\section{Diatom assemblages}

Diatom assemblages were analyzed to estimate the mud source (Additional file 2: Fig. S2). We sampled the tsunami mud layers at 5 sites (GPS21, 0-6 cm depth; GPS42, $4.5-5.0 \mathrm{~cm}$ depth; GPS172, $0-3 \mathrm{~cm}$ depth; GPS182, 0-2.5 cm depth; GPS185, $0-3 \mathrm{~cm}$ and $3-9 \mathrm{~cm}$ depth; Fig. 1c), rice paddy soil at 1 site (GPS12, 6.5-7.5 $\mathrm{cm}$ depth; Fig. 1c), and bottom sediment of the pond at 1 site (GPS 7, 29-30 cm depth; Fig. 1c). Diatom identification and nomenclature were based on methods described by Kosugi (1988) and Ando (1990).

\section{Estimating erosional and depositional volume attributable to the tsunami}

Using densely collected sedimentary data, the onshore deposit volumes of sand and mud based on the deposition area and interpolated thickness distribution were estimated by the use of Geographic Information System (GIS). The natural neighbor interpolation method (Sibson 1981) was employed to estimate the onshore deposit volumes. In addition, we estimated the erosional volume attributable to the tsunami using DEMs, aerial photographs, satellite images, topographic maps, and field data. Pre-tsunami (February 2006) and post-tsunami (March and October 2011) DEMs with grid size $2 \mathrm{~m}$ and aerial photographs provided by the Geospatial Information Authority of Japan (GSI) were used for comparing between the deposit distribution and the topographic features and for estimating the erosional volume. Satellite images, aerial photographs, and topographic maps taken before and after the tsunami were analyzed to estimate the erosional features and erosion areas. Considering co-seismic subsidence by the 2011 earthquake, elevation of the post-tsunami was shifted by $0.26 \mathrm{~m}$ based on geodetic observation data (GSI Maps provided by GSI, https://maps.gsi.go.jp/).

\section{Results}

Hydrodynamic behavior of tsunami waves

Analysis of aerial photographs, taken on March 12, 2011, indicated that the 2011 Tohoku-oki tsunami fully inundated the main valley and sub-valleys (Fig. 1b). The maximum inundation distance was $2.2 \mathrm{~km}$ from the shoreline. The maximum run-up height is T.P. 14.6$16.4 \mathrm{~m}$ at the hill along the shoreline (Fig. 1b). It reached T.P. $12.8 \mathrm{~m}$ at the valley head of main valley (Fig. 2c). The maximum flow height along the shoreline is T.P. 8.9-11.4 m.

Eyewitness accounts of local people described wave hydrodynamic behavior of the 2011 tsunami in this area. (1) Before the arrival of the first incoming wave, the sea level receded rapidly. The shallow seafloor was exposed a few hundred meters offshore from the coast. (2) About $1 \mathrm{~h}$ after the main shock, the tsunami inundated the valley and reached the top of Isozakiyama Park (Fig. 1b, T.P. 17-18 m) (Kahoku Online News, published on May 14, 2011, https://www.kahoku.co.jp/special/spe1168/201 80226_01.html). (3) At least three incoming waves overtopped the seawall and sand dune. (4) Backwash discharged rubbles into the sea.

\section{Erosion by the tsunami}

Comparison of aerial photographs taken on March 12, 2011, and in October 2006 indicated extensive erosional features along the coast (Fig. 1b). The tsunami severely eroded the sandy beach and sand dune (Fig. 2a, Additional file 2: Fig. S1). In particular, the tsunami flow caused scouring of the ground and sand dune behind the seawall. Most of the pine trees on sand dune were bent landward. According to field observations, the soil erosion area in the rice paddy was more than approx. $90 \%$ in the lower main valley. In contrast, it was less than about $10 \%$ in the upper main valley and sub-valleys. 


\section{Deposition by the tsunami Tsunami deposit thickness}

Among 174 survey sites, traces of tsunami inundation and deposition were well preserved at 166 sites in the valley. The tsunami traces at 8 other sites were disturbed by post-tsunami human activities. Although the tsunami deposits were identified at 155 sites, we observed no erosion of pre-existing sediments or no deposition caused by the 2011 tsunami at 9 sites in the main valley and sub-valleys except for 2 sites in sand dune (Fig. 1b). Tsunami deposits generally comprise a combination of sand and mud layers. Their total thickness (sum of thicknesses of sand and mud layers) was $0-40 \mathrm{~cm}$ in the lower main valley and the pond (Fig. 3a, b). Up to $0.1 \mathrm{~km}$ inland from the shoreline, either erosion of the surficial soil or lack of deposition of tsunami sand/mud was evident on the sandy beach and the sand dune. Between 0.1 and $2.2 \mathrm{~km}$ inland, the tsunami deposits were mostly distributed everywhere. The total thickness of the deposits generally decreased landward, but it fluctuated locally (Fig. 3a, b).

Sand layers were identified at 150 sites. The sand layers reached near the inundation limit in the main valley (Fig. 3a). They were composed mainly of fine-grained to medium-grained sand, showing either sharp or unclear erosional contact with underlying sediments. The sand mostly comprised light minerals such as quartz and feldspar grains, but it also contained heavy minerals such as mica, pyroxene, and magnetite grains. Thin laminae (less than 1-2 mm thick), which are characterized by magnetite concentration, were observed inside the sand layer at some sites. Shell fragments were rarely observed inside the sand layers. The sandy tsunami deposit was composed of either single or multiple sub-unit(s) (Fig. $2 f, h)$. Sand layers with single unit were mostly observed on the upper main valley and sub-valleys. Sand layers with multiple sub-units were observed on the lower main valley and in the pond. Figure 3 a shows the total sand thickness, which is defined by the sum of the thickness of sub-units of the sand layer. The total sand thickness generally decreased landward (Figs. 3a and 4a).

Mud layers were observed at 102 sites. Distribution of the mud layers was mostly limited to the rice paddy and the pond (Fig. 3b). The mud layer was composed of clay to silt, but it included floating debris and vegetation fragments, with precipitation of salt on the surface. The mud layers formed either a surface mud cap or a mud drape between sub-units of sand layers. In Fig. 3b, the total mud thickness is defined by the sum of thicknesses of the surface mud cap plus the mud drape at each site. The total mud thickness was $0-40 \mathrm{~cm}$ at each area (Figs. $3 \mathrm{~b}$ and $5 \mathrm{a})$. Up to $0.4 \mathrm{~km}$ inland from the shoreline, which includes the sandy beach, sand dune, and residential areas, no mud layer was observed. Between 0.4 and $0.7 \mathrm{~km}$ inland, the mud cap thickness was less than a few centimeters. The total mud thickness increased to $40 \mathrm{~cm}$ in and around the pond. From 0.9 to $2.2 \mathrm{~km}$ inland, the total mud layer thickness was a few centimeters, with local fluctuation (Figs. 3b and 5a).

We compared the deposit thickness (sand, mud) and the elevation of the bottom of the tsunami deposit using the post-tsunami DEM with grid size $2 \mathrm{~m}$ (Figs. $4 \mathrm{~b}$ and $5 \mathrm{~b})$. The total sand thickness was well correlated to the elevation of the bottom in the upper main valley, and in the south and north sub-valleys (Fig. 4b). Relations between mud thickness and the elevation of the bottom are unclear in all topographic types (Fig. 5b).

\section{Sedimentary structures}

Normal grading, inverse grading, parallel lamination, mud clasts, and mud drape were observed inside the tsunami deposit. Each sedimentary structure was observed only inside the sand layer, although the mud layer was massive, with no structures.

Sand layers with normal grading were observed at 42 sites. The layers were distributed between 0.27 and 1.72 $\mathrm{km}$ inland from the shoreline (Fig. 6a) and between -2.0 and $8.4 \mathrm{~m}$ in elevation. Sand layers with normal grading were rarely observed at the places with a steep slope in the main valley and sub-valleys (Fig. 6a).

Sand layers with inverse grading were observed at 4 sites. The layers were distributed between 0.6 and $1.2 \mathrm{~km}$ inland from the shoreline (Fig. 6a), and between 0.7 and $1.9 \mathrm{~m}$ in elevation. Distribution of the layers was concentrated at the center of the lower main valley (Fig. 6a).

Sand layers with parallel lamination were observed at 37 sites. The parallel lamination was observed as concentrations of coarse-grained particles or heavy minerals, with thicknesses of $1 \mathrm{~mm}$ to a few centimeters (Fig. 2e). The laminated layer distributions extended between 0.2 and $1.2 \mathrm{~km}$ inland from the shoreline (Fig. $6 \mathrm{~b}$ ), and from 0.5 to $4.8 \mathrm{~m}$ in elevation. The layers were only observed at the lower main valley and the north sub-valley.

Sand layers with mud clasts (a few centimeters in length) (Fig. 2f) were observed at 34 sites and were mostly distributed on the rice paddies or in the pond between 0.5 and $1.8 \mathrm{~km}$ inland (Fig. 6b), and between -2.0 and $5.8 \mathrm{~m}$ in elevation. The layers were rarely observed at the seaward side of the lower main valley.

Sand layers bounded by mud drapes (less than several millimeters in thickness) were observed at 10 sites. Mud drapes were distributed at distances between 0.6 and 1.6 $\mathrm{km}$ from the shoreline (Fig. $6 \mathrm{~b}$ ). The layers were mostly observed at the lower main valley and the pond.

Sand layers composed of multiple sub-units were observed at 51 sites. The sand layers with multiple subunits were generally thicker than the sand layers with a single unit (Figs. 3a and 6c). The number of sub-units decreased landward with increasing elevation (Fig. 6c). 


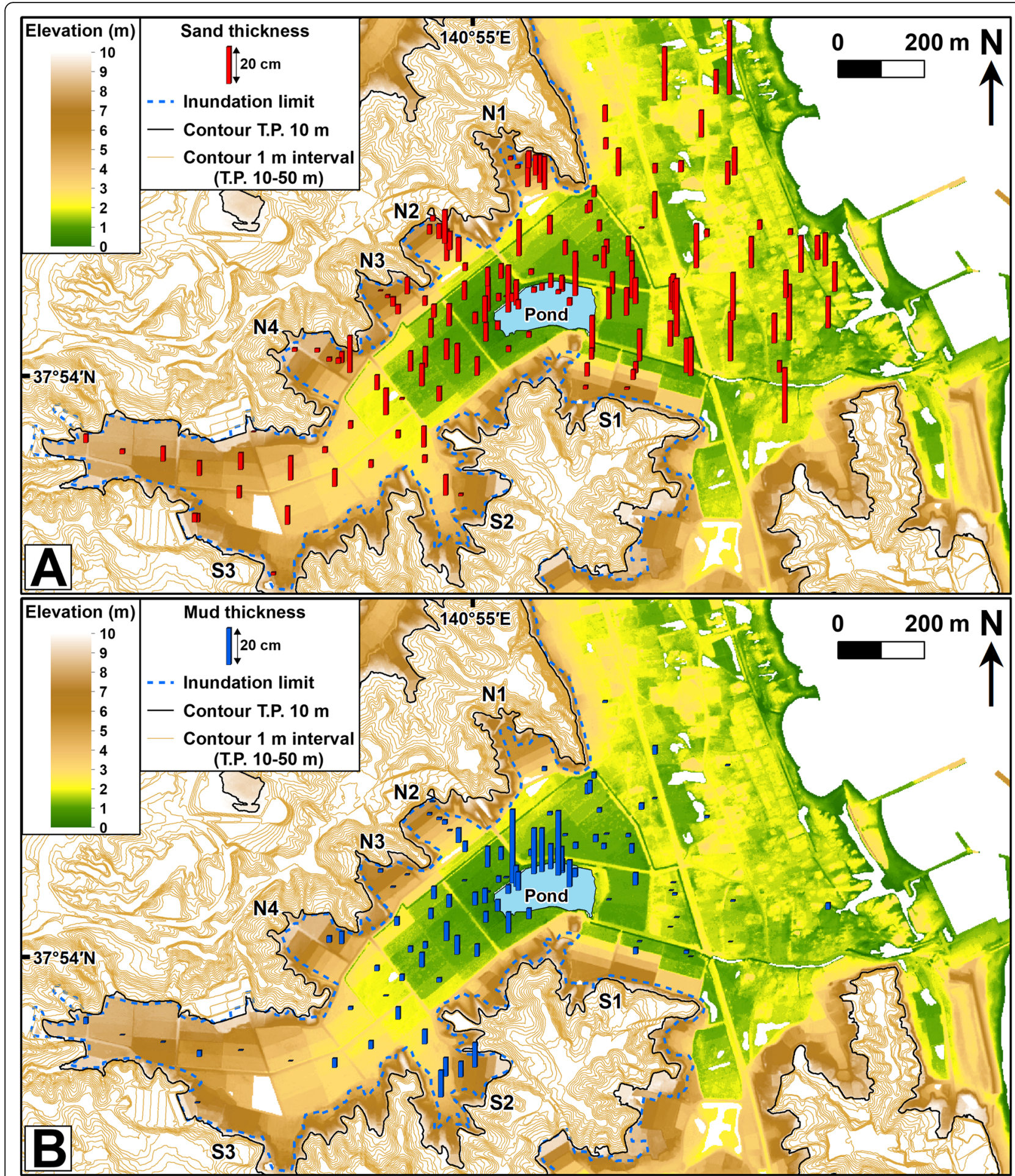

Fig. 3 Spatial thickness distribution of $\mathbf{a}$ tsunami sand and $\mathbf{b}$ tsunami mud. Elevation map and contour line are based on the $2 \mathrm{~m}$ grid DEM data provided by GSI. N, north sub-valley; S, south sub-valley

Sand layers with multiple sub-units were characteristically observed in the lower main valley and the pond. However, sand layers with a single unit were mostly observed in the upper main valley and sub-valleys.
Grain size distribution

In the lower main valley, median grain size and grain size sorting respectively ranged $1.4-2.4$ phi and $0.4-0.7$, and in the upper main valley and sub-valleys, respectively ranged 

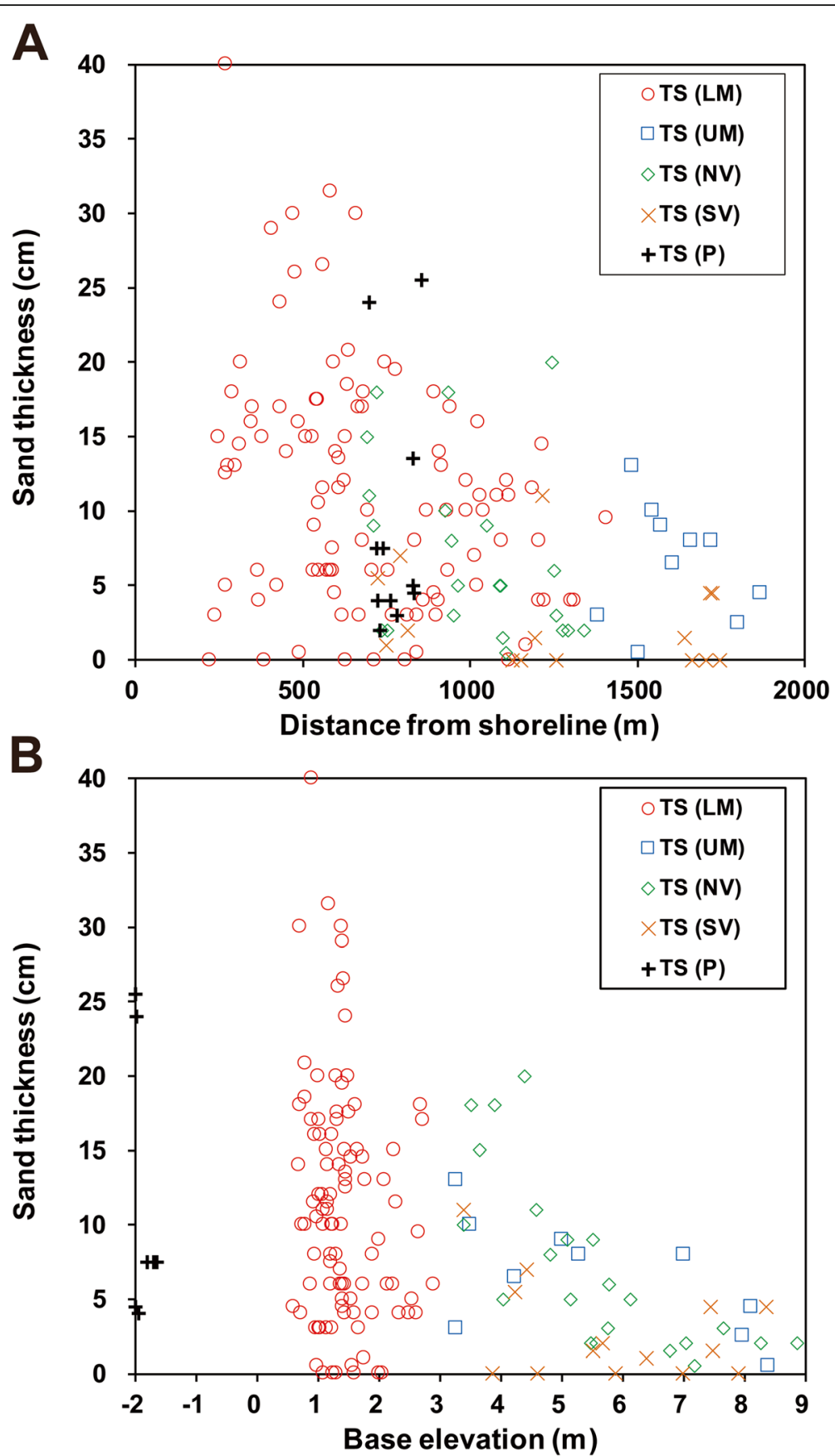

Fig. 4 Thicknesses of tsunami sand shown by each topographic type against the inland distance from the shoreline (a) and the base elevation (b). Control point of measurement of the distance from the shoreline is shown in Fig. 1b. Base elevation means the elevation (above T.P.) of the bottom of tsunami deposit. TS, tsunami sand layer; LM, lower main valley; UM, upper main valley; NV, north sub-valley; SV, south sub-valley; $P$, pond

1.7-2.1 phi and 0.4-0.5 (Fig. 7a-c and Additional file 1: Table S1). Fluctuation of the median grain size with increasing shore-normal distance in the lower main valley was found to be greater than that in the upper main valley and sub-valleys (Fig. 7b). In addition, the sand layer generally became finer landward in the upper main valley (Fig. 7b). Grain size characteristics were similar among the tsunami sand layer, beach sand, and dune sand (Fig. 7a). The seafloor sands were clearly separated from these sands in terms of the median grain size and grain size sorting (Fig. 7a).

\section{Diatom assemblages}

Regarding the diatom analysis for the mud component, species were generally similar among all sites (Fig. 8, 


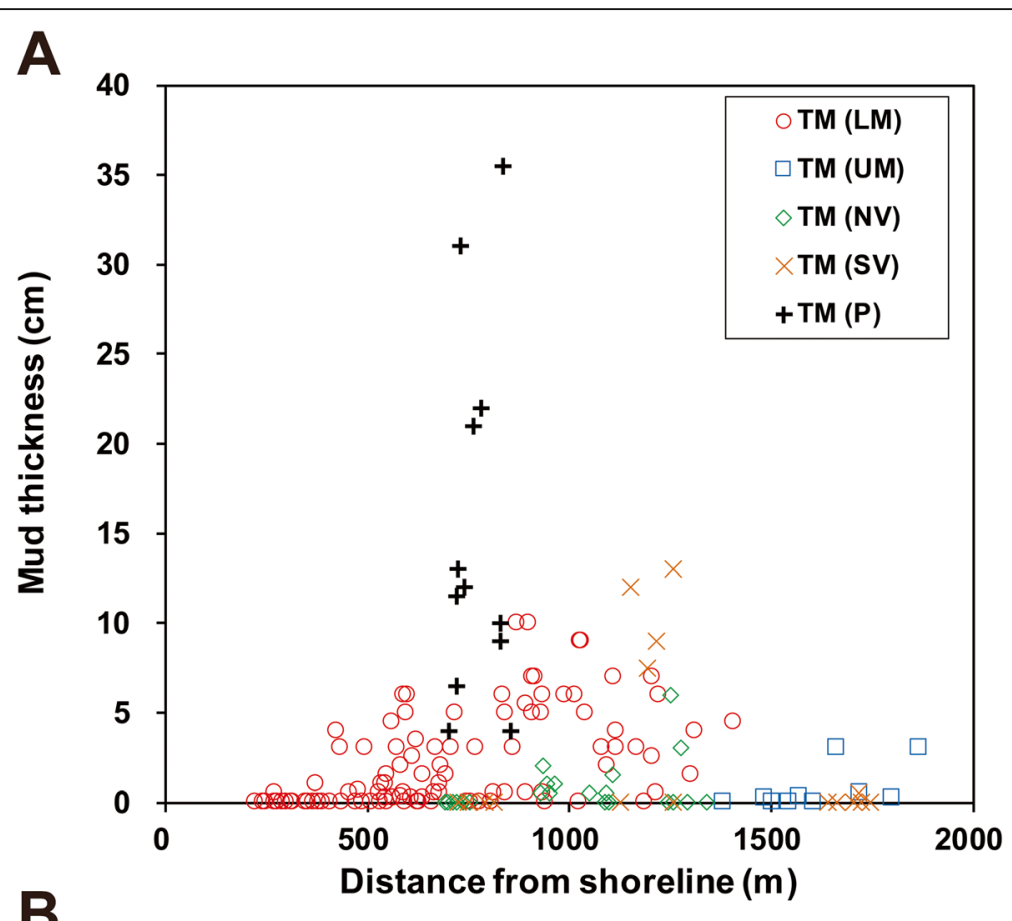

B

Distance from shoreline (m)

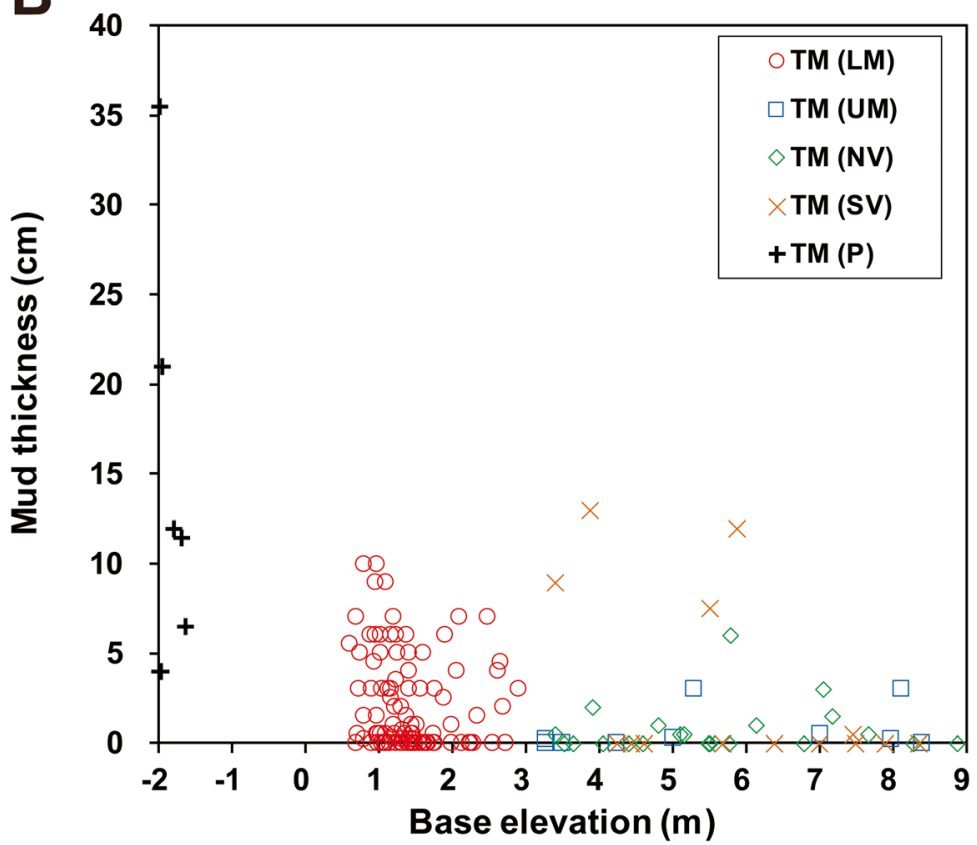

Fig. 5 Thicknesses of tsunami mud shown by each topographic type against the inland distance from the shoreline (a) and the base elevation (b). Base elevation means the elevation (above T.P.) of the bottom of tsunami deposit. TM, tsunami mud layer; LM, lower main valley; UM, upper main valley; NV, north sub-valley; SV, south sub-valley; P, pond

Table 2, and Additional file 1: Table S2). Freshwater species (e.g., Aulacoseira ambigua, Aulacoseira distans, Aulacoesira italica, Aulacoseira spp., Fragilaria brevistriata, Fragilaria construens, Fragilaria pinnata, Fragilaria spp., Pinnularia spp.) dominated (88-93\%) the assemblages in all samples. Samples include a few marine diatom species (2-7\%), and brackish species (1-5\%) were found in the pond sediment (14\%) and tsunami mud (9-19\%), but not rice paddy soil $(0 \%)$.

\section{Estimating the sediment budget}

The area and volume of the terrestrial erosion of sand, distributed on sandy beach and sand dune, were estimated respectively as $7.85 \times 10^{4} \mathrm{~m}^{2}$ and $1.34 \times 10^{5} \mathrm{~m}^{3}$ 


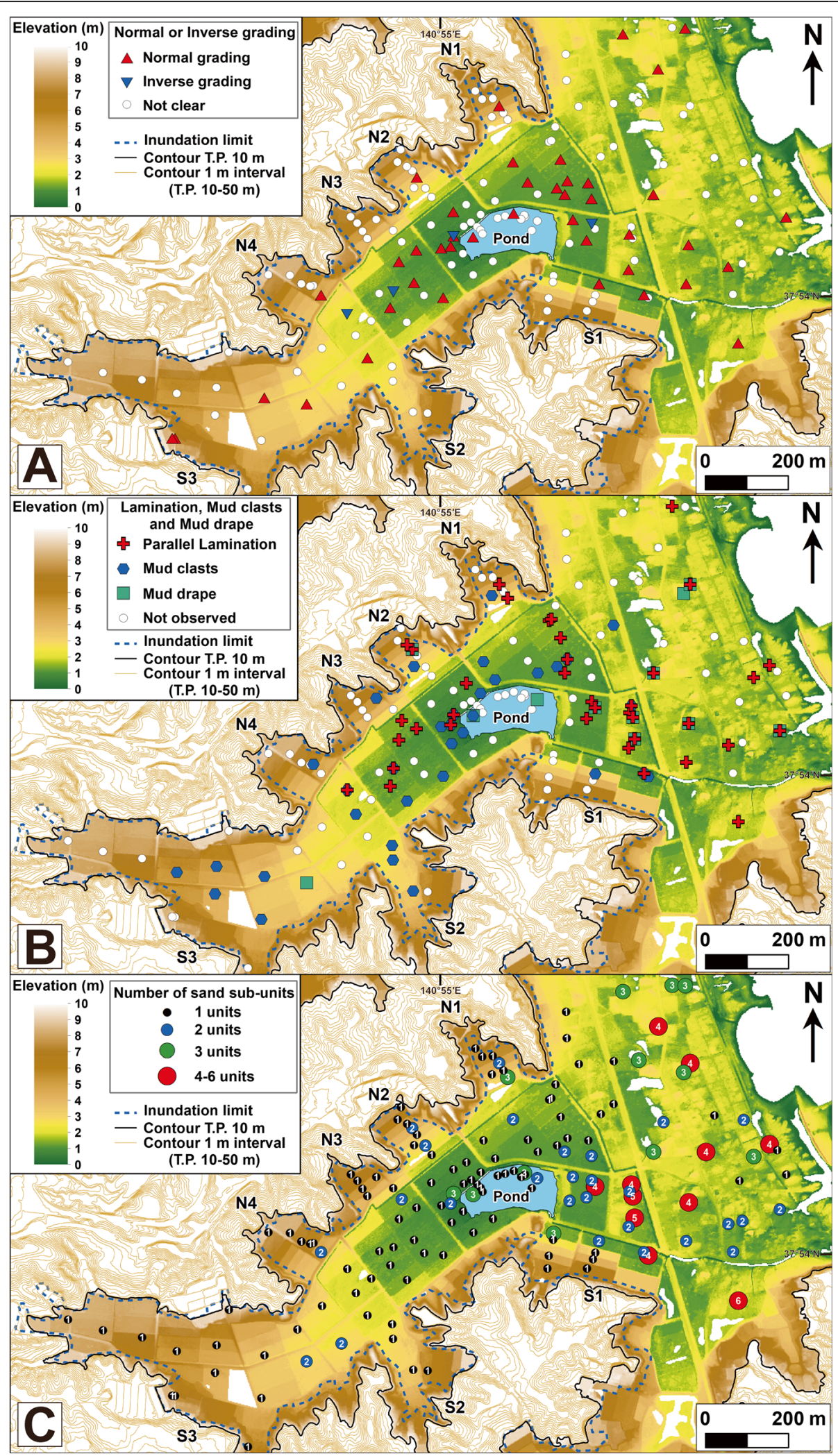

Fig. 6 Spatial distribution of sedimentary structures: a normal grading and inverse grading; $\mathbf{b}$ parallel lamination, mud clasts, and mud drape; and c number of sand sub-units. Elevation map and contour line are based on the $2 \mathrm{~m}$ grid DEM data provided by GSI 

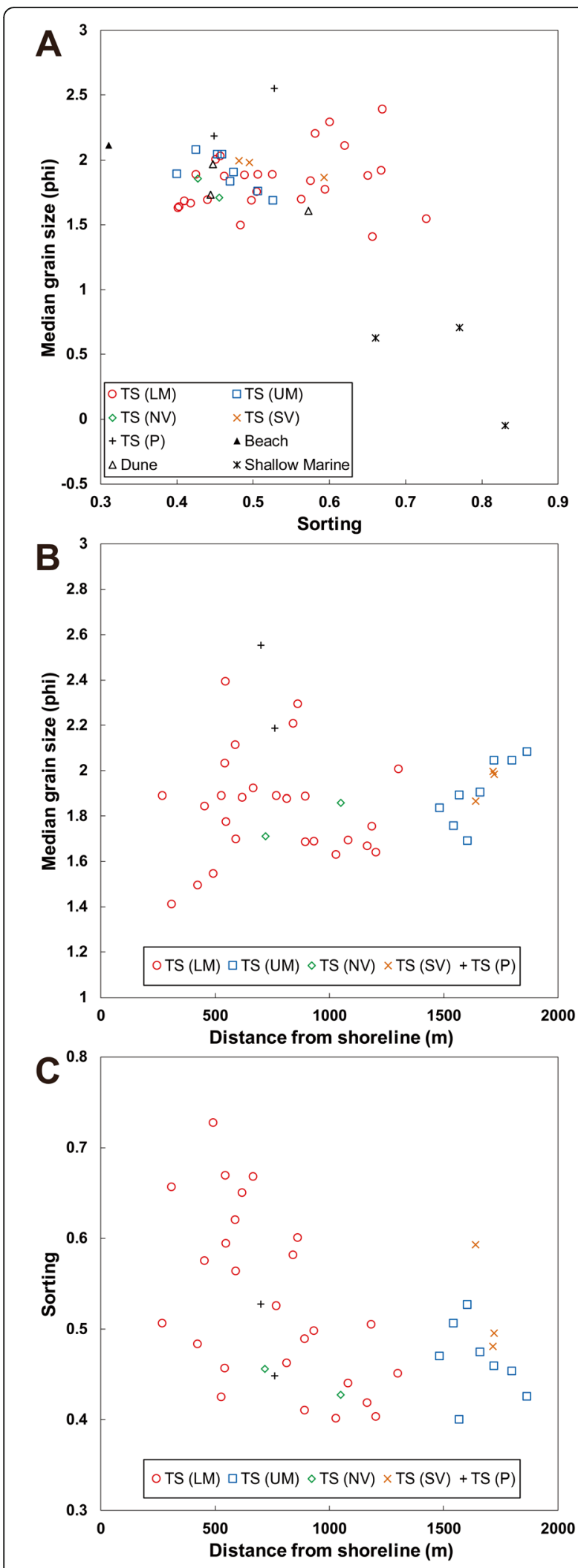

Fig. 7 Median grain size and grain size sorting of tsunami sand, dune sand, beach sand, and shallow marine sand. a Median grain size of sand shown by topographic type against grain size sorting. Results of shallow marine sand sampled off the coast of the valley were from Ohshima et al. (1986). b Median grain size shown by each topographic type against distance from the shoreline. c Grain size sorting shown by each topographic type against distance from the shoreline. Locations of the sampling site are shown in Fig. 1c. TS, tsunami sand layer; LM, lower main valley; UM, upper main valley; NV, north sub-valley; SV, south sub-valley; P, pond

based on a comparison of pre-tsunami and post-tsunami aerial photographs and DEMs (Fig. 9a and Table 3). Average erosional depth in mud erosional areas (paddy fields) was approximately estimated as $0.1 \mathrm{~m}$ based on field observations and interviews to local farmers. The area and volume of the terrestrial erosion of the mud were estimated respectively as $2.55 \times 10^{5} \mathrm{~m}^{2}$ and $2.55 \times$ $10^{4} \mathrm{~m}^{3}$ based on field observations, aerial photograph analysis, and interviews as described above (Fig. 9a and Table 3).

Sand and mud depositional areas were estimated respectively as $6.98 \times 10^{5} \mathrm{~m}^{2}$ and $6.94 \times 10^{5} \mathrm{~m}^{2}$ (Table 3) by a field observation and spatial analysis using GIS. We employed natural neighbor interpolation method to estimate spatial variations in thickness and onshore depositional volume (Fig. 9b, c). Consequently, depositional volumes of sand and mud were roughly estimated respectively as $7.65 \times 10^{4} \mathrm{~m}^{3}$ and $1.34 \times 10^{4} \mathrm{~m}^{3}$. According to comparison between depositional and erosional volumes, the estimated sand and mud depositional volumes respectively accounted for $57 \%$ and $52 \%$ of erosional volumes (Table 3).

\section{Discussion}

\section{Sediment sources and budget}

Sediment sources

Judging from a comparison of aerial photographs and DEMs obtained before and after the 2011 tsunami, tsunami flow eroded the sandy beach and sand dune (Figs. $1 \mathrm{~b}$ and $9 \mathrm{a})$. Grain size distributions of beach and dune sands and the sandy portion of tsunami deposits were similar (Fig. 7a, median grain size $1.5-2.5$ phi). Grain size distributions of the seafloor sands before the 2011 tsunami, which were sampled from offshore sea bottom (12-23 m depth) off the coast of the valley, were much coarser (Fig. 7a, median grain size $-0.1-0.7$ phi) than the onshore deposits. Shell fragments were rarely observed in the tsunami deposits. These lines of evidence suggest that sediment supply from the seafloor might not have been dominant.

This interpretation was supported by earlier reported data of mineral composition and microfossil assemblages of 2011 tsunami deposits in coastal area along Sendai Bay. Jagodziński et al. (2012) reported that heavy mineral 


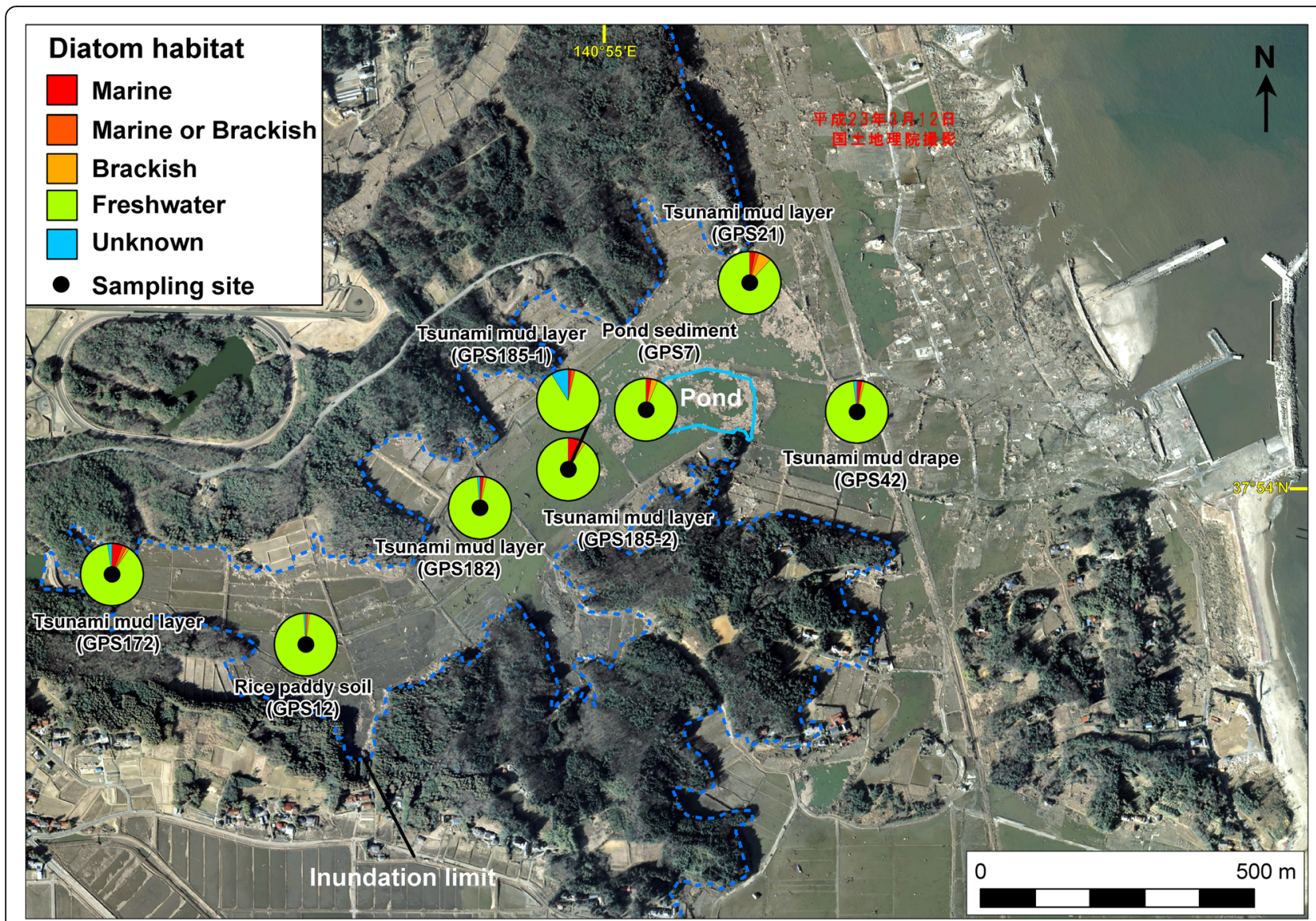

Fig. 8 Diatom assemblages of tsunami mud, pond sediment, and rice paddy soil. The circular chart shows percentages of marine, marine or brackish, brackish, and freshwater species. Base map is an aerial photograph taken on the day after the tsunami which was provided by GSI. Diatom identification and habitat were based on methods described by Kosugi (1988) and Ando (1990)

concentrations and assemblages were similar between the tsunami deposit and the sandy beach on Sendai Plain. Both Szczuciński et al. (2012) and Takashimizu et al. (2012) reported few brackish-marine diatoms of the sandy tsunami deposit along a shore-normal transect on Sendai Plain. Putra et al. (2013) described minor foraminifera populations in the sandy tsunami deposits and similar foraminifera densities between the beach sand, dune sand, and sandy tsunami deposits, which were sampled along a transect on the coastal lowland $20 \mathrm{~km}$ south of our study area. These earlier works indicate the main source of the sandy tsunami deposit not as offshore sediments but as onshore sediments including beach and dune sands.

Onshore sediment sources are supported not only by microfossil assemblages, but also by numerical modeling.

Table 2 Diatom assemblage analysis results

\begin{tabular}{llllllll}
\hline Sample name & Sediment type & Depth (cm) & Marine (\%) & Brackish (\%) & Marine-brackish (\%) & Freshwater (\%) & Unknown (\%) \\
\hline GPS7 & Pond sediment & $29-30$ & 2.8 & 3.3 & 0.9 & 93.0 & 0.0 \\
GPS12 & Rice paddy soil & $6.5-7.5$ & 1.0 & 1.0 & 1.0 & 96.0 & 1.0 \\
GPS21 & Tsunami mud layer & $0-6$ & 2.9 & 6.8 & 2.0 & 87.8 & 0.5 \\
GPS172 & Tsunami mud layer & $0-3$ & 5.6 & 1.4 & 2.3 & 88.3 & 2.3 \\
GPS182 & Tsunami mud layer & $0-2.5$ & 1.9 & 1.4 & 0.5 & 94.7 & 1.4 \\
GPS185-1 & Tsunami mud layer & $0-3$ & 1.5 & 0.5 & 2.0 & 87.2 & 8.9 \\
GPS185-2 & Tsunami mud layer & $3-9$ & 5.3 & 2.4 & 1.4 & 90.3 & 0.5 \\
GPS42 & Tsunami mud drape & $4-5$ & 2.7 & 1.3 & 0.4 & 93.8 & 1.8 \\
\hline
\end{tabular}

Sampling site locations were shown in Figs. 1c and 8. Major species of each sample were shown in Additional file 1: Table S2. Diatom identification and habitat were based on methods described by Kosugi (1988) and Ando (1990) 


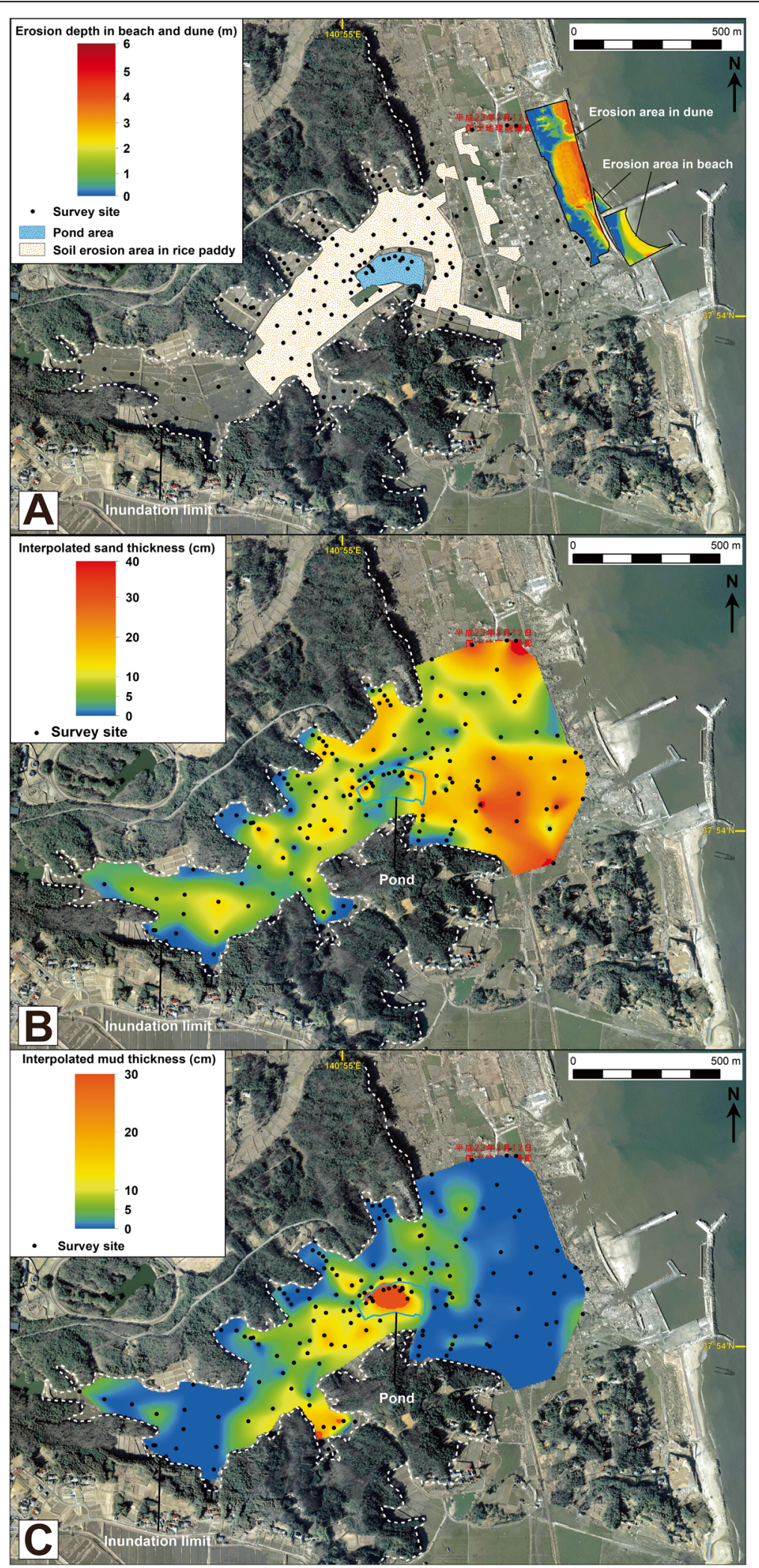

Fig. 9 Estimation of erosion and deposition by the tsunami in study area: a a sand erosion depth in sandy beach and sand dune, and a soil erosion area in a rice paddy; $\mathbf{b}$ spatial distribution of interpolated sand thickness; and $\mathbf{c}$ spatial distribution of interpolated mud thickness. Base map is an aerial photograph taken on the day after the tsunami which was provided by GSI 
Table 3 Estimation of erosion and deposition by the tsunami in study area

\begin{tabular}{llll}
\hline Erosion & & & \\
& Area $\left(\mathrm{m}^{2}\right)$ & Depth $(\mathrm{m})$ & Volume $\left(\mathrm{m}^{3}\right)$ \\
Sand & $7.85 \times 10^{4}$ & $0-6.1$ & $1.34 \times 10^{5}$ \\
Mud & $2.55 \times 10^{5}$ & 0.1 (Ave.) & $2.55 \times 10^{4}$ \\
Deposition & & & \\
& Area $\left(\mathrm{m}^{2}\right)$ & Thickness $(\mathrm{m})$ & Volume $\left(\mathrm{m}^{3}\right)$ \\
Sand & $6.98 \times 10^{5}$ & $0-0.4$ & $7.65 \times 10^{4}$ \\
Mud & $6.94 \times 10^{5}$ & $0-0.4$ & $1.34 \times 10^{4}$ \\
& & & \\
Depositional volume / Erosional volume & \\
Sand & & $57 \%$ & \\
Mud & & $52 \%$ & \\
\hline
\end{tabular}

Tsunami sediment transport modeling demonstrated that the steep nearshore bathymetry in the central Sendai Bay promoted decreasing shear velocity at the seafloor in the offshore and preventing sediment resuspension from the seafloor around the coastal area (Sugawara et al. 2014). Yoshikawa et al. (2018) also conducted a numerical simulation of tsunami sediment transport near the area examined for the present study. Although the local bathymetry is slightly shoaling comparing to that of central Sendai Bay, they concluded that sediment resuspension from the seafloor is minor even during maximum inflow. Consequently, it is reasonable to infer that the sand layer is predominantly sourced from the sandy beach and sand dune, but not from the seafloor. Locally, it seemed that the source area in sandy beach and sand dune was influenced by arrangement of artificial structures such as coastal dikes and developed land. In fact, erosion depth reached to $6 \mathrm{~m}$ at landward side of the coastal dike in studied area (Fig. 9a). Numerical simulation demonstrated that sediment erosion was intense behind the coastal dikes due to the increased flow speeds in Sendai Plain (Sugawara et al. 2014). Therefore, it is required for application of paleo-tsunami to carefully consider effects of artificial structures on sediment transport by tsunami.

Diatom assemblages of muddy tsunami deposit mostly comprise freshwater species and are similar with those of rice paddy soil and pond sediment (Table 2, Additional file 1: Table S2). Hence, diatom assemblages of the mud layer demonstrated that the mud was mostly sourced from the rice paddies and the pond. Field observation and interviews of local farmers also revealed that rice paddy soil, which might have typical thickness of $0.2 \mathrm{~m}$, was approx. $0.1 \mathrm{~m}$ thick on average, eroded by the tsunami in paddy fields. In addition, the depositional area of the mud layer coincides with the distribution of the rice paddies and the pond location. It is unlikely that the mud was transported from offshore because the shallow seafloor sediment was mostly composed of sand (Ohshima et al. 1986). Therefore, the main source area of the mud layer is identifiable as the rice paddies and the pond (Fig. 9a).

\section{Sediment budget}

The depositional volume of the sand layer $\left(7.65 \times 10^{4}\right.$ $\mathrm{m}^{3}$, Table 3) and mud layer $\left(1.34 \times 10^{4} \mathrm{~m}^{3}\right.$, Table 3$)$ can be explained well by the erosional volume of the beach and dune sands $\left(1.34 \times 10^{5} \mathrm{~m}^{3}\right.$, Table 3$)$ and the mud from the paddies and the pond $\left(2.55 \times 10^{4} \mathrm{~m}^{3}\right.$, Table 3$)$ because the erosional volume is far larger than the depositional volume. As shown in Table 3, this finding in turn suggests that $57 \%$ and $52 \%$ of the erosional volume of the sand and the mud were discharged into the sea by the backwash. Udo et al. (2013) investigated beach morphology changes along the $3 \mathrm{~km}$ long coast including our study area and estimated that $75 \%$ of the total amount of eroded coastal sand was transported seaward by backwash. Differences in estimation between this study and Udo et al. (2013) probably derived from the estimated area. Udo et al. (2013) estimated the total balance along $3 \mathrm{~km}$ long coast, but our estimation is limited along the $1 \mathrm{~km}$ long coast. Based on high-resolution seismic surveys and coring, Yoshikawa et al. (2015) confirmed that considerable amounts of sediments have been transported by the backwash and they were deposited on the shoreface.

\section{Control factors of thickness distribution}

Generally speaking, tsunami deposits thinned inland in low-lying coastal plains (e.g., Shi et al. 1995; Gelfenbaum and Jaffe 2003; Hori et al. 2007; Fujino et al. 2010; Richmond et al. 2012). In our studied valley, the sand thickness also generally decreased landward (Figs. 3a and 4a) and showed negative correlation with the elevation (Fig. $4 \mathrm{~b})$. This decreasing trend is probably related to the reduction of sediment supply and sediment transport capacity. The sediment supply possibly decreased during tsunami inundation: the flow traveled longer distance and reached a higher elevation from the sediment source. That decreased sediment supply probably engenders formation of the thinner deposit. Sediment transport capacity would have decreased concomitantly with decreasing flow velocity and depth.

Besides, the sand thickness did not decrease linearly landward (Fig. 4a). It spatially fluctuated because of micro-landforms of the valley (Figs. 3a and 9). For example, the sand thickness decreased across stepwise topographic features in north and south sub-valleys (N1-N4 and S1 in Fig. 3a). The sand thickness is widely known to have fluctuated with topographic irregularities 
and obstacles, which locally caused changes in tsunami behavior (Nishimura and Miyaji 1995; Hori et al. 2007; Nakamura et al. 2012; Matsumoto et al. 2016). The sand thickness distribution pattern varied depending on the topography in the valley. The sand layer generally thinned landward with local fluctuation in the lower main valley (Figs. 3a, 4a, and 9b). Flow velocity and depth of the incoming wave might have been less affected by the flat topography of the lower main valley (Fig. 1b). Consequently, the sediment transport capacity is apparently nearly constant in the lower main valley; decreased sand supply from the sand dune and sandy beach might be key factors of inland thinning. By contrast, the sand layer thinned landward in the upper main valley and sub-valleys (Figs. 3a and 4a). The sand thickness is also related to the base elevation in these areas (Fig. 4b). Bedload transport is likely restricted by microlandforms such as high mounds and stepwise features; most of the sand layer found from the higher places is possibly deposited from suspension. Therefore, landward and upward thinning trends in these areas might be affected by decreasing flow depth, velocity, and capacity of the suspended load (Hiscott 1994).

No clear landward trend of the mud layer thickness is apparent: it increased rapidly in and around the pond (Figs. 3b and 9c). This increase occurs because the mud layer was sourced not only from the paddy soil but also from the bottom sediment of the pond. Therefore, local sources played an important role in affecting the mud layer thickness.

\section{Factors affecting sedimentary structures}

Sedimentary structures of sandy tsunami deposits provided useful information for estimating the sedimentary processes and flow condition (Fujiwara and Tanigawa 2014). Distribution patterns of the respective sedimentary structures were controlled by the inland distance and micro-landforms in our study area. Here, we describe major sedimentary structures in relation to the topography.

\section{Normal grading}

Normal grading was common among tsunami deposits (Peters and Jaffe 2010). Grain sizes of the sand layers that fine upward are usually explained as the product of suspended sediment settling from a decelerating flow (Jaffe and Gelfenbaum 2007; Naruse et al. 2010; Moore et al. 2011). From field observation and grain size analysis of the 2011 tsunami deposit, Szczuciński et al. (2012) inferred forming process of upward fining inside sandy tsunami deposit as follows. (1) Since sandy tsunami deposits with upward finning are at the same time laminated, they were likely still in traction transport after deposition from suspension. (2) The sand layer might be settled from flowing water-deceleration of flow reduces the transport capacity of larger grains first, so they are deposited first. In our study area, sand layers with normal grading were observed in the main valley $(0.2-1.8$ $\mathrm{km}$ inland from the shoreline), where the slope of topography was gentle (Fig. 6a, Additional file 2: Fig. S3). This gradual slope in turn suggested that decelerating flow dominantly occurred in this area: inundated water tended to stagnate in the lower elevation area (Udo et al. 2013).

\section{Inverse grading}

Overall inverse grading of tsunami deposits is rare (Morton et al. 2008), but it was sometimes recognized in the 2004 Indian Ocean tsunami and the 2011 tsunami sands (e.g., Naruse et al. 2010; Naruse et al. 2012; Szczuciński et al. 2012; Koiwa et al. 2014). Naruse et al. (2010) inferred that the inverse graded layers are a consequence of the waxing stage of the oscillatory flows caused by the tsunami waves. In our study area, a sand layer with inverse grading was found at the central part of the lower main valley from 0.6 to $1.2 \mathrm{~km}$ inland from the shoreline (Fig. 6a, Additional file 2: Fig. S3). Sustained acceleration of the flow can be expected to lead to a sustained increase in transport rate of coarser grains. The local topography in the study area is characterized by a low-lying depression near the pond. This topographic setting might lead to acceleration of the flow toward the pond area, particularly the inflow from the shoreline to the pond area and the return flow from the upper main valley and sub-valleys to the pond area, which induced formative condition of the inverse grading of the tsunami deposits (Fig. 6a).

\section{Parallel lamination}

Parallel lamination is frequently identified in sandy tsunami deposits (Naruse et al. 2010; Peters and Jaffe 2010; Nakamura et al. 2012). Parallel lamination is formed by plane beds, implying bedload transport of sediments (Bridge and Best 1988). Sand layers with parallel lamination were distributed between 0.2 and $1.2 \mathrm{~km}$ inland in our study area (Fig. 6b). However, although parallel lamination might be useful to estimate the minimum velocity necessary to form it (Southward and Boguchwal 1990; Ohata et al. 2017), it is difficult to estimate the maximum velocity using laminated layers. Parallel lamination in the valley was characterized by concentrations of coarser grains or heavy minerals. Landward limits of the parallel lamination suggest inland decreasing in these grains as an indicator of the minimum flow velocity. This interpretation is supported by grain size sorting and median grain size of the sand (Fig. 7b, c). Nakamura et al. (2012) and Jagodziński et al. (2012) showed that a heavy mineral fraction of the 2011 
tsunami sand decreased landward, and that landward change in the ratio between light minerals and heavy minerals has potential for use as an indicator of the sediment transportation modes (suspension/traction carpet) and transport distance from the source of the sand such as sandy beaches and sand dunes.

\section{Mud clasts}

Mud clasts, also known as rip-up clasts, were formed from erosion of muddy bottom sediments ( $\mathrm{Li}$ et al. 2017) and were related to increasing critical shear stresses of the bottom (Talling et al. 2002). Mud clasts were often observed in sandy tsunami deposits (e.g., Richmond et al. 2012; Putra et al. 2013; Ishizawa et al. 2018). In our study area, mud clasts (a few centimeters in length) were distributed from 0.5 to $1.8 \mathrm{~km}$ inland (Fig. 6b). It is highly likely that mud clasts were originated from the rice paddy soil based on the distribution (Fig. 9a) and components of the mud clasts. The marked erosion of the paddy soil below the tsunami deposit also supports this interpretation. Mud clasts in the sand layer suggest that large traction by the tsunami inundation flow was maintained at least up to $1.8 \mathrm{~km}$ inland from the shoreline.

\section{Mud drape}

Multiple sub-units of tsunami sand were occasionally separated by mud drapes up to several millimeters thick (e.g., Fujiwara and Kamataki 2007). Mud drapes were formed in the process of suspension of muddy sediments during the standing wave between the numbers of the waves (Fujiwara and Kamataki 2007; Naruse et al. 2010). In our study area, mud drapes in the sand layers existed up to $1.8 \mathrm{~km}$ inland, where the topography is characterized by gentle slopes (Fig. 6b). Consequently, results suggest that multiple waves with long periods inundated the area and that the water stagnated because of the gentle slope up to $1.8 \mathrm{~km}$ inland. Lack of mud drapes in the upper main valley and sub-valleys suggests that these higher places were inundated by the main wave.

\section{Multiple sand units}

Multiple sand units were presumably formed by independent waves (Nanayama and Shigeno 2006). In our study area, the number of sand sub-units decreased inland (Fig. 6c). The maximum inland distances of 1-6 sub-units were $0.6-1.9 \mathrm{~km}$. In particular, the sand layer, which was composed of 3-6 sub-units, was mostly distributed up to $0.6 \mathrm{~km}$ inland from the shoreline. They also diminished with increasing elevation (Fig. 6c). The maximum height of 1-6 sub-units was T.P. $1.5-8.9 \mathrm{~m}$. The sand layer with 3-6 sub-units concentrated at the place of less than T.P. $3 \mathrm{~m}$. The maximum number of sub-units is a double of number of incoming waves based on eyewitness accounts. Although each sand subunit was likely to have been formed by independent waves, reworking of earlier formed tsunami deposit(s) must be considered in any attempt to correlate the numbers of sub-units and waves. Therefore, the number of the sand sub-units should be regarded as the minimum number of waves that formed the sand layers. Multiple sand sub-units were mostly observed in the lower main valley, whereas single sand unit was observed in the upper main valley and sub-valley. Our findings of the effects of maximum waves, according to data observed using GPS tide gauges (Kawai et al. 2013), suggest that the first wave was more than $3 \mathrm{~m}$ high. However, the direction of run-up flow is known to be almost perpendicular to the shoreline, whereas backwash flow directions were likely affected strongly by local topography, as reported by Umitsu et al. (2007).

Consequently, spatial fluctuations of the sand units in the lower main valley of our study site might be attributable to differences in the influences on tsunami sedimentation process associated with the arrangement in space of micro-landforms such as small mounds, steps, old ponds, and old channels.

\section{Relations among topography, tsunami behavior, and sedimentary process}

Sedimentary processes of recent tsunami events were estimated based on tsunami deposit characteristics (Nanayama and Shingeno 2006; Paris et al. 2007; Choowong et al. 2008; Szczuciński et al. 2012; Takashimizu et al. 2012; Putra et al. 2013). In the case of the 2011 tsunami, the flow height of first wave is greater than that of later waves along Sendai Bay (Kawai et al. 2013). Consequently, sedimentation and erosion by the inflow and outflow of the first wave are certainly greater than those by the following waves. In the valley, the sandy tsunami deposits consisted of 1-6 sub-units; meanwhile, the sand layer in a low-lying section in Sendai Plain mostly comprised single unit (Szczuciński et al. 2012; Takashimizu et al. 2012). These differences suggest that steep slope and narrow depositional area of valleys contribute to the formation of multiple sand sub-units.

In the valley, sediment supply from onshore sources including sandy beach, sand dune, paddy field, and pond is more dominant than that from offshore. This appears to be similar to Sendai Plain (Szczuciński et al. 2012; Takashimizu et al. 2012). However, several earlier reports of studies examining recent tsunami events have described that onshore tsunami deposits include offshore sediment (e.g., Gelfenbaum and Jaffe 2003; Nanayama and Shingeno 2006; Naruse et al. 2012). Characteristics of incoming tsunami waves, such as amplitude and period, and local bathymetry largely have been considered to control incorporation of marine components in 
tsunami deposits (Goto et al. 2014). Sugawara (2017) examined differences in sediment sources of onshore tsunami deposits regarding the bottom shear velocity of inflow based on numerical simulation, and concluded that local bathymetry plays an important role for nearshore hydrodynamic characteristics of tsunami-induced flow, which finally determine whether or not the shear velocity can be large enough to transport seafloor sediments inland. The local bathymetry of the study area is characterized by a gentler offshore sloping, comparing with that of Sendai Plain (e.g., Goto et al. 2012); nevertheless, the gentler bathymetry did not cause difference in the transport of seafloor sediments.

We estimated that $57 \%$ and $52 \%$ of the erosional volume of the sand and the mud were discharged into the sea by the backwash. The onshore slope from the shoreline to inundation limits (T.P. $12.8 \mathrm{~m}$ ) at the valley head in the upper main valley was $5.9 \%$ in the valley. MacInnes et al. (2009) examined tsunami deposits on high-relief coastal topography of the Kuril Island along four shore-normal transects with $0.12-0.43 \mathrm{~km}$ in length and estimated that $76-98 \%$ of the sediments in the source region were discharged into the sea by outflow (MacInnes et al. 2009). In their study sites, the onshore slope ranged $25.5-54.9 \%$ from the shoreline to the inundation limit (5.7-18.1 $\mathrm{m}$ above mean sea level) (MacInnes et al. 2009). MacInnes et al. (2009) argued that the tsunami was dominantly erosive in the Kuril Islands because the high-relief topography of the shoreline accelerated tsunami outflow. The balance between the volume of erosion and deposition is likely controlled by the run-up height related to onshore slope of the inundation area and behavior and height of the wave on the coast.

The balance between erosion and deposition was examined also by flume experiments (e.g., Hasegawa et al. 2001; Yoshii et al. 2017, 2018). Hasegawa et al. (2001) carried out the flume experiment with land slope of $50 \%$ and found that approx. $60 \%$ of onshore depositional volume, which was transported by run-up flow, was discharged into the sea by return flow. Yoshii et al. $(2017,2018)$ performed the flume experiment with three cases of land slope $(0 \%, 10 \%, 20 \%)$ and showed that land slope plays an important role in balance between sediment supply resulting from inflow and sediment remigration attributed to outflow. The role of tsunami as a geomorphological agent, which is reflected to patterns of tsunami-induced erosion and deposition, can sometimes be very different between valleys and coastal plains. Estimations of the erosional volume of recent tsunamis are rare in the literature (e.g., Paris et al. 2009; Udo et al. 2013; MacInnes et al. 2009). In the future, not only deposition amounts, but also amounts of erosion must be examined immediately after the tsunami to elucidate factors controlling sediment budget, combined with further knowledge from flume experiments and numerical simulations.

\section{Conclusions}

This study investigated the spatial distribution of thickness, sedimentary structures, and grain sizes of the 2011 Tohoku-oki tsunami deposits in a narrow valley setting. In the valley, spatial variations of them were likely controlled by local topography and the arrangement in space of micro-landforms. This finding in turn suggests that transect surveys in a valley setting might not be valid to elucidate sedimentary processes comprehensively. At our site, differences of observations between the transect survey and spatial survey were similar in areas with higher than $3 \mathrm{~m}$ in elevation, although they differed in areas with lower than $3 \mathrm{~m}$ in elevation because multiple waves and backwash led to fluctuation of the deposit thickness at lower elevation areas, whereas the influence of sediment transport by multiple waves was minor for higher elevations. Therefore, spatial variations of the deposit distribution should be investigated carefully in low elevation areas, where the deposition pattern was more sensitive to multiple waves than the high elevation areas. Although the influence of sediment transport by multiple waves is probably more complicated in a narrow valley with steep slope than low-lying coastal plains in general, there were advantages and disadvantages for understating sedimentary processes and reconstructing hydraulic characteristics of paleo-tsunami with each setting. While a large $(\sim 2 \mathrm{~km})$ gap was often known between the inundation limit and the maximum landward extent of the recognizable sand layer in lowlying plains (e.g., Goto et al. 2011; Abe et al. 2012), both were almost the same in the valley, as well as previous study of recent tsunami deposits in steep valley (MacInnes et al. 2009). These findings imply that the maximum inland extent of the tsunami sand is possible to be good proxy for estimating the inundation area of paleo-tsunami in steep valley. The issue of potential linkage between the number of sub-units and wave behavior could be subjected to deeper analysis in the future. Our results are presented as a template for recent examples for studying paleo-tsunami deposits in narrow valleys. Paleo-tsunami research in narrow valleys can be expected to open new avenues for collecting useful geological data from locations that have not been heretofore regarded as amenable to research in this field.

\section{Supplementary information}

Supplementary information accompanies this paper at https://doi.org/10. 1186/s40645-019-0318-6.

Additional file 1: Table S1. Results of grain-size analysis by settling tube method. All grain-size values are shown phi scale. The sampling sites 
are shown in Fig. 1C. LM: lower main valley, UM: upper main valley, NV: north sub-valley, SV: south sub-valley, P: pond, B: beach, SD: sand dune. Table S2. Results of analysis of diatom assemblage. Only the common species are presented. The sampling sites are shown in Fig. 1c.

Additional file 2: Fig. S1. Oblique aerial photographs in our study area taken by The Geospatial Information Authority of Japan on May 25, 2011. (A) View from offshore. (B) View from valley head. Fig. S2. Examples of diatom species in the muddy deposits: 1. Fragilaria pinnata, 2. Navicula salinarum, 3. Rhopalodia operculata, 4. Navicula cincta. 5. Cyclotella meneghiniana, 6. Hyalodiscus scoticus, 7. Aulacoseira distans, 8. Synedra tabulata, 9. Nitzschia plana, 10. Neidium alpinum, 11. Pinnularia gibba, 12 Nitzschia calida, 13. Navicula elegans, 14. Navicula radiosa, 15. Navicula crucicula, 16. Navicula cryptocephala, 17. Cymbella gracilis, 18. Pinnularia viridis, 19. Diploneis ellipica, 20, Mastogloia pumila, 21. Rhopalodia gibberula, 22. Thalassiosira bramaputrae, 23. Melosira undulata, 24. Mastogloia pumila, 25. Synedra nanana, 26. Pinnularia nodosa, 27. Nitzschia acuminata, 28. Gomphonema acuminatum, 29. Hantzschia amphioxys. Fig. S3. Vertical variation of the tsunami deposit at GPS 206. The sand layer is characterized by inverse-graded and normal-graded multiple units. The observation site is shown in Fig. 1c. TS: Tsunami sand layer. TM: Tsunami mud layer. Soil: Pre-tsunami soil.

\section{Abbreviations}

DEM: Digital elevation model; DGPS: Differential Global Positioning System; GIS: Geographic Information System; GSI: Geospatial Information Authority of Japan; T.P.: Tokyo Peil; TETJSG: The 2011 Tohoku Earthquake Tsunami Joint Survey Group

\section{Acknowledgements}

We appreciate the local people and Yamamoto Town for their support during the field survey. We also thank Dr. Witold Szczuciński and an anonymous reviewer for their valuable suggestions and comments.

\section{Authors' contributions}

TA proposed the topic, and conceived and designed the study. TA, KG, and DS conducted the field survey. TA analyzed the data. KG and DS collaborated with the corresponding author in the construction of manuscript. All authors read and approved the final manuscript.

\section{Funding}

This research was supported by a research grant from the International Research Institute of Disaster Science, Tohoku University.

\section{Availability of data and materials}

Please contact author for data requests.

\section{Competing interests}

The authors declare that they have no competing interests.

\section{Author details}

${ }^{1}$ Geological Survey of Japan, National Institute of Advanced Industrial Science and Technology (AIST), 1-1-1 Higashi, Tsukuba, Ibaraki 305-8567, Japan. ${ }^{2}$ International Research Institute of Disaster Science, Tohoku University, 468-1 Aramaki Aza-Aoba, Aoba-ku, Sendai, Miyagi 980-0845, Japan. ${ }^{3}$ Department of Earth and Planetary Science, The University of Tokyo, 7-3-1 Hongo, Bunkyo-ku, Tokyo 113-0033, Japan. ${ }^{4}$ Curatorial Division, Museum of Natural and Environmental History, Shizuoka, 5762 Oya, Suruga-ku, Shizuoka 422-8017, Japan

Received: 12 June 2019 Accepted: 24 December 2019 Published online: 08 February 2020

\section{References}

Abe T, Goto K, Sugawara D (2012) Relationship between the maximum extent of tsunami sand and the inundation limit of the 2011 Tohoku-oki tsunami on the Sendai Plain, Japan. Sedimentary Geology 282:142-150 https://doi.org/10. 1016/j.sedgeo.2012.05.004

Ando K (1990) Environmental indicators based on freshwater diatom assemblages and its application to reconstruction of paleo-environments.
Annals of The Tohoku Geographical Association 42:73-88 (in Japanese with English abstract) https://doi.org/10.5190/tga1948.42.73

Apotsos A, Gelfenbaum G, Jaffe B, Watt S, Peck B, Buckley M, Stevens A (2011) Tsunami inundation and sediment transport in a sediment-limited embayment on American Samoa. Earth-Science Reviews 107:1-11 https://doi. org/10.1016/j.earscirev.2010.11.001

Atwater BF (1987) Evidence for great Holocene earthquakes along the outer coast of Washington state. Science 236:942-944 https://science.sciencemag. org/content/236/4804/942

Bridge JS, Best JL (1988) Flow, sediment transport and bedform dynamics over the transition from dunes to upper-stage plane beds: implications for the formation of planar laminae. Sedimentology 35:753-763 https://doi.org/10. 1111/j.1365-3091.1988.tb01249.x

Choowong M, Murakoshi N, Hisada K, Charusiri P, Charoentitirat T, Chutakositkanon V, Phantuwongraj S (2008) 2004 Indian Ocean tsunami inflow and outflow at Phuket, Thailand. Marine Geology 248:179-192 https:// doi.org/10.1016/j.margeo.2007.10.011

Dawson AG, Long D, Smith DE (1988) The Storegga Slides: evidence from eastern Scotland for a possible tsunami. Marine Geology 82:271-276. https://doi.org/ 10.1016/0025-3227(88)90146-6

Fujino S, Kimura H, Komatsubara J, Matsumoto D, Namegaya Y, Sawai Y, Shishikura M (2018) Stratigraphic evidence of historical and prehistoric tsunamis on the Pacific coast of central Japan: implications for the variable recurrence of tsunamis in the Nankai Trough. Quaternary Science Reviews 201:147-161 https://doi.org/10.1016/j.quascirev.2018.09.026

Fujino S, Naruse H, Matsumoto D, Sakakura N, Suphawajruksakul A, Jarupongsakul $T$ (2010) Detailed measurements of thickness and grain size of a widespread onshore tsunami deposit in Phang-nga Province, southwestern Thailand. Island Arc 19:389-398 https://doi.org/10.1111/j.1440-1738.2010.00730.x

Fujiwara O, Kamataki T (2007) Identification of tsunami deposits considering the tsunami waveform: an example of subaqueous tsunami deposits in Holocene shallow bay on southern Boso Peninsula, Central Japan. Sedimentary Geology 200:295-313 https://doi.org/10.1016/j.sedgeo.2007.01.009

Fujiwara O, Tanigawa K (2014) Bedforms record the flow conditions of the 2011 Tohoku-Oki tsunami on the Sendai Plain, northeast Japan. Marine Geology 358:79-88 https://doi.org/10.1016/j.margeo.2014.04.013

Gelfenbaum G, Jaffe B (2003) Erosion and sedimentation from the 17 July, 1998 Papua New Guinea Tsunami. Pure and Applied Geophysics 160:1969-1999 https://doi.org/10.1007/s00024-003-2416-y

Goff J, Chagué-Goff C, Nichol S, Jaffe B, Dominey-Howes D (2012) Progress in palaeotsunami research. Sedimentary Geology 243-244:70-88 https://doi. org/10.1016/j.sedgeo.2011.11.002

Goto K, Chagué-Goff C, Fujino S, Goff J, Jaffe B, Nishimura Y, Yulianto E (2011) New insights of tsunami hazard from the 2011 Tohoku-oki event. Marine Geology 290:46-50 https://doi.org/10.1016/j.margeo.2011.10.004

Goto K, Fujima K, Sugawara D, Fujino S, Imai K, Tsudaka R, Abe T, Haraguchi T (2012) Field measurements and numerical modeling for the run-up heights and inundation distances of the 2011 Tohoku-oki tsunami at Sendai Plain, Japan. Earth, Planets and Space 64:1247-1257 https://doi.org/10.5047/eps. 2012.02.007

Goto K, Ikehara K, Goff J, Chagué-Goff C, Jaffe B (2014) The 2011 Tohoku-oki tsunami-three years on. Marine Geology 358:2-11 https://doi.org/10.1016/j. margeo.2014.08.008

Goto T, Satake K, Sugai T, Ishibe T, Harada T, Gusman AR (2017) Effects of topography on particle composition of 2011 tsunami deposits on the riatype Sanriku coast, Japan. Quaternary International 456:17-27 https://doi.org/ 10.1016/j.quaint.2017.05.014

Goto T, Satake K, Sugai T, Ishibe T, Harada T, Gusman AR (2019) Tsunami history over the past 2000 years on the Sanriku coast, Japan, determined using gravel deposits to estimate tsunami inundation behavior. Sedimentary Geology 382:85-102 https://doi.org/10.1016/j.sedgeo.2019.01.001

Goto T, Satake K, Sugai T, Ishibe T, Harada T, Murotani S (2015) Historical tsunami and storm deposits during the last five centuries on the Sanriku coast, Japan. Marine Geology 367:105-117 https://doi.org/10.1016/j. margeo.2015.05.009

Hasegawa S, Takahashi T, Uehata Y (2001) Hydraulic experiment on sediment due to tsunami run-up. Proceedings of Coastal Engineering, JSCE 48:311-315 (in Japanese) https://doi.org/10.2208/proce1989.48.311

Hiscott RN (1994) Traction-carpet stratification in turbidites; fact or fiction? Journal of Sedimentary Research 64:204-208 https://doi.org/10.1306/ D4267D57-2B26-11D7-8648000102C1865D 
Hori K, Kuzumoto R, Hirouchi D, Umitsu M, Janjirawuttikul N, Patanakanog B (2007) Horizontal and vertical variation of 2004 Indian tsunami deposits: an example of two transects along the western coast of Thailand. Marine Geology 239:163-172 https://doi.org/10.1016/j.margeo.2007.01.005

Inoue T, Goto K, Nishimura Y, Watanabe M, lijima Y, Sugawara D (2017) Paleotsunami history along the northern Japan Trench: evidence from Noda Village, northern Sanriku coast, Japan. Progress in Earth and Planetary Science 4:42. doi.org/10.1186/s40645-017-0158-1

Ishimura D, Miyauchi T (2015) Historical and paleo-tsunami deposits during the last 4000 years and their correlations with historical tsunami events in Koyadori on the Sanriku Coast, northeastern Japan. Progress in Earth and Planetary Science 2:16 https://doi.org/10.1186/s40645-015-0047-4

Ishizawa T, Goto K, Yokoyama Y, Miyairi Y, Sawada C, Takada K (2018) Reducing the age range of tsunami deposits by $14 \mathrm{C}$ dating of rip-up clasts. Sedimentary Geology 364:334-341 https://doi.org/10.1016/j.sedgeo.2017.09.008

Jaffe BE, Gelfenbuam G (2007) A simple model for calculating tsunami flow speed from tsunami deposits. Sedimentary Geology 200:347-361 https://doi. org/10.1016/j.sedgeo.2007.01.013

Jagodziński R, Sternal B, Szczuciński W, Chagué-Goff C, Sugawara D (2012) Heavy minerals in the 2011 Tohoku-oki tsunami deposits-insights into sediment sources and hydrodynamics. Sedimentary Geology 282:57-64 https://doi.org/ 10.1016/j.sedgeo.2012.07.015

Kawai H, Satoh M, Kawaguchi K, Seki K (2013) Characteristics of the 2011 Tohoku Tsunami Waveform Acquired Around Japan by Nowphas Equipment Coastal Engineering Journal, 55:(3)1350008-1-1350008-27 https://doi.org/10.1142/ S0578563413500083 https://www.tandfonline.com/doi/abs/10.1142/S05 78563413500083

Koiwa N, Kasai M, Kataoka S, Isono T (2014) Examination of relation with tsunami behavior reconstructed from on-site sequence photographs, topography, and sedimentary deposits from the 2011 Tohoku-oki tsunami on the Kamikita Plain, Japan. Marine Geology 358:107-119 https://doi.org/10.1016/j. margeo.2014.08.009

Kosugi M (1988) Classification of living diatom assemblages as the indicator of environments, and its application to reconstruction of paleoenvironments. The Quaternary Research (Daiyonki-Kenkyu) 27:1-20 (in Japanese with English abstract) https://doi.org/10.4116/jaqua.27.1

Kusumoto S, Goto T, Sugai T, Omori T, Satake K (2018) Geological evidence of tsunamis in the past 3800 years at a coastal lowland in the central Fukushima Prefecture, Japan. Marine Geology 404:137-146 https://doi.org/10. 1016/j.margeo.2018.07.004

Li S, Li S, Shan X, Gong C, Yu X (2017) Classification, formation, and transport mechanisms of mud clasts. International Geology Review 59:1609-1620 https://doi.org/10.1080/00206814.2017.1287014

Maclnnes BT, Bourgeois J, Kravchunovskaya EA, Pinegina TK (2009) Tsunami geomorphology: erosion and deposition from the 15 November 2006 Kuril Island tsunami. Geology 37:995-998 https://doi.org/10.1130/G30172A.1

Matsumoto D, Sawai Y, Tanigawa K, Fujiwara O, Namegaya Y, Shishikura M, Kimura H (2016) Tsunami deposit associated with the 2011 Tohoku-oki tsunami in the Hasunuma site of the Kujukuri coastal plain, Japan. Island Arc 25:369-385 https://doi.org/10.1111/iar.12161

Matsumoto H (1981) Sea-level changes during the Holocene and geomorphic developments of the Sendai coastal plain, northeastern Japan. Geographical Review of Japan 54:72-85 (in Japanese with English abstract) https://doi.org/ 10.4157/grj.54.72

Minoura K, Nakaya S (1991) Traces of tsunami preserved in inter-tidal lacustrine and marsh deposits: some examples from northeast Japan. The Journal of Geology 99:265-287 https://doi.org/10.1086/629488

Moore A, Goff J, McAdoo BG, Fritz HM, Gusman A, Kalligeris N, Synolakis CE (2011) Sedimentary deposits from the 17 July 2006 Western Java Tsunami, Indonesia: use of grain size analyses to assess tsunami flow depth, speed, and traction carpet characteristics. Pure and Applied Geophysics 168:19511961 https://doi.org/10.1007/s00024-011-0280-8

Mori N, Takahashi T \& THE 2011 TOHOKU EARTHQUAKE TSUNAMI JOINT SURVEY GROUP (2012) Nationwide Post Event Survey and Analysis of the 2011 Tohoku Earthquake Tsunami. Coastal Engineering Journal, 54:1, 1250001-11250001-27 https://doi.org/10.1142/S0578563412500015 https://www. tandfonline.com/doi/abs/10.1142/S0578563412500015

Morton RA, Goff JR, Nichol SL (2008) Hydrodynamic implications of textural trends in sand deposits of the 2004 tsunami in Sri Lanka. Sedimentary Geology 207:56-64 https://doi.org/10.1016/j.sedgeo.2008.03.008
Nakamura Y, Nishimura Y, Putra P (2012) Local variation of inundation, sedimentary characteristics, and mineral assemblages of the 2011 Tohoku-oki tsunami on the Misawa coast, Aomori, Japan. Sedimentary Geology 282:216227 https://doi.org/10.1016/j.sedgeo.2012.06.003

Nanayama F, Shigeno K (2006) Inflow and outflow facies from the 1993 tsunami in southwest Hokkaido. Sedimentary Geology 187:139-158 https://doi.org/10. 1016/j.sedgeo.2005.12.024

Naruse H, Arai K, Matsumoto D, Takahashi H, Yamashita S, Tanaka G, Murayama M (2012) Sedimentary features observed in the tsunami deposits at Rikuzentakata City. Sedimentary Geology 282:199-215 https://doi.org/10. 1016/j.sedgeo.2012.08.012

Naruse H, Fujino S, Suphawajruksakul A, Jarupongsakul T (2010) Features and formation processes of multiple deposition layers from the 2004 Indian Ocean Tsunami at Ban Nam Kem, southern Thailand. Island Arc 19:399-411 https://doi.org/10.1111/j.1440-1738.2010.00732.x

Nishimura Y, Miyaji N (1995) Tsunami deposits from the 1993 Southwest Hokkaido earthquake and the 1640 Hokkaido Komagatake eruption, northern Japan. Pure and Applied Geophysics 144:719-733 https://doi.org/10.1007/ BF00874391

Ohata K, Naruse H, Yokokawa M, Viparelli E (2017) New bedform phase diagrams and discriminant functions for formative conditions of bedforms in openchannel flows. Journal of Geophysical Research: Earth Surface 122:2139-2158 https://doi.org/10.1002/2017JF004290

Ohshima K, Yokota S, Saito Y, Suzuki T, Matsumoto E, Ikeda K, Hasaka T (1986) Anthropogenic influence of the sedimentary regime of an open type bay: Sendai Bay. Study on the feedback and mechanism of human activities impact on the dynamic-geomorphology of Lingding Bay of Pearl River Estuary in latest 100 years (NSFC No.41476049). (in Japanese with English abstract)

Paris R, Lavigne F, Wassmer P, Sartohadi J (2007). Coastal sedimentation associated with the December 26, 2004 tsunami in Lhok Nga, west Banda Aceh (Sumatra, Indonesia), Marine Geology 238(1-4):93-106. https://doi.org/ 10.1016/j.margeo.2006.12.009. https://www.sciencedirect.com/science/article/ pii/S0025322706003653

Paris R, Wassmer P, Sartohadi J, Lavigne F, Barthomeuf B, Desgages E, Gomez C (2009) Tsunamis as geomorphic crises: lessons from the December 26, 2004 tsunami in Lhok Nga, West Banda Aceh (Sumatra, Indonesia). Geomorphology 104:59-72 https://doi.org/10.1016/j.geomorph.2008.05.040

Peters R, Jaffe B (2010) Identification of tsunami deposits in the geologic record; developing criteria using recent tsunami deposits. U.S. Geological Survey Open-File Report 2010-1239. http://pubs.usgs.gov/of/2010/1239/

Putra PS, Nishimura Y, Nakamura Y, Yulianto E (2013) Sources and transportation modes of the 2011 Tohoku-Oki tsunami deposits on the central east Japan coast. Sedimentary Geology 294:282-293 https://doi.org/10.1016/j.sedgeo. 2013.06.004

Richmond B, Szczuciński W, Chagué-Goff C, Goto K, Sugawara D, Witter R, Goff J (2012) Erosion, deposition and landscape change on the Sendai coastal plain, Japan, resulting from the March 11, 2011 Tohoku-oki tsunami. Sedimentary Geology 282:27-39 https://doi.org/10.1016/j.sedgeo.2012.08.005

Sawai Y, Fujii Y, Fujiwara O, Kamataki T, Komatsubara J, Okamura Y, Shishikura M (2008) Marine incursions of the past 1500 years and evidence of tsunamis at Suijin-numa, a coastal lake facing the Japan Trench. The Holocene 18:517528 https://doi.org/10.1177/0959683608089206

Shanmugam G (2012) Process-sedimentological challenges in distinguishing paleo-tsunami deposits. Natural Hazards 63:5-30 https://doi.org/10.1007/ s11069-011-9766-z

Shi S, Dawson AG, Smith DE (1995) Coastal sedimentation associated with the December 12th, 1992 tsunami in Flores, Indonesia. Pure and Applied Geophysics 144:525-536 https://doi.org/10.1007/BF00874381

Shimada Y, Fujino S, Sawai Y, Tanigawa K, Matsumoto D, Momohara A, Chagué C (2019) Geological record of prehistoric tsunamis in Mugi town, facing the Nankai Trough, western Japan. Progress in Earth and Planetary Science 6:33. doi.org/10.1186/s40645-019-0279-9

Shinozaki T, Goto K, Fujino S, Sugawara D, Chiba T (2015) Erosion of a paleo-tsunami record by the 2011 Tohoku-oki tsunami along the southern Sendai Plain. Marine Geology 369:127-136 https:/doi.org/10.1016/j.margeo.2015.08.009

Sibson R (1981) A brief description of natural neighbor interpolation. Interpreting Multivariate Data:21-36

Southward JB, Boguchwal LA (1990) Bed configuration in steady unidirectional water flows; part 2, synthesis of flume data. Journal of 
Sedimentary Research 60:658-679 https://doi.org/10.1306/212F9241-2B2411D7-8648000102C1865D

Sugawara D (2017) Tsunami sedimentation and deposits from the 2011 Tohoku earthquake: a review of case studies from Sendai and Hirota Bays. The Journal of the Geological Society of Japan 123:781-804 (in Japanese with English abstract) https://doi.org/10.5575/geosoc.2017.0047

Sugawara D, Takahashi T, Imamura F (2014) Sediment transport by the 2011 Tohoku-oki tsunami at Sendai: results from numerical modeling. Marine Geology 358:18-37 https://doi.org/10.1016/.j.margeo.2014.05.005

Southard JB, Boguchwal LA (1990) Bed configuration in steady unidirectional water flows; Part 2, Synthesis of flume data Journal of Sedimentary Research; 60(5):658-679. https://doi.org/10.1306/212F9241-2B24-11D78648000102C1865D https://pubs.geoscienceworld.org/sepm/jsedres/article/6 0/5/658/98211/Bed-configuration-in-steady-unidirectional-water

Szczuciński W, Kokociński M, Rzeszewski M, Chagué-Goff C, Cachão M, Goto K, Sugawara D (2012) Sediment sources and sedimentation processes of 2011 Tohoku-oki tsunami deposits on the Sendai Plain, Japan-insights from diatoms, nannoliths and grain size distribution. Sedimentary Geology 282:4056 https://doi.org/10.1016/.jsedgeo.2012.07.019

Takashimizu Y, Urabe A, Suzuki K, Sato Y (2012) Deposition by the 2011 Tohoku-ok tsunami on coastal lowland controlled by beach ridges near Sendai, Japan. Sedimentary Geology 282:124-141 https://doi.org/10.1016/j.sedgeo.2012.07.004

Talling PJ, Peakall J, Sparks RSJ, Ó Cofaigh C, Dowdeswell JA, Felix M, Weaver PPE (2002) Experimental constraints on shear mixing rates and processes: implications for the dilution of submarine debris flows. Geological Society, London, Special Publications 203:89-103. https://doi.org/10.1144/GSL.SP.2002. 203.01.06

Udo K, Tanaka H, Mono A, Takeda Y (2013) Beach morphology change of southern Sendai Coast caused by the 2011 Tohoku Earthquake Tsunami. Journal of Japan Society of Civil Engineers, Ser. B2 (Coastal Engineering) 69:1 1391-I_1395. (in Japanese with English abstract) https://doi.org/10.2208/ kaigan.69.I_1391

Umitsu M, Tanavud C, Patanakanog B (2007) Effects of landforms on tsunami flow in the plains of Banda Aceh, Indonesia, and Nam Khem, Thailand. Marine Geology 242:141-153 https://doi.org/10.1016/j.margeo.2006.10.030

Weiss R, Bourgeois J (2012) Understanding sediments-reducing tsunami risk. Science 336:1117-1118 https://doi.org/10.1126/science.1221452

Yamada M, Fujino S, Goto K (2014) Deposition of sediments of diverse sizes by the 2011 Tohoku-oki tsunami at Miyako City, Japan. Marine Geology 358:6778 https://doi.org/10.1016/j.margeo.2014.05.019

Yoshii T, Tanaka S, Matsuyama M (2017) Tsunami deposits in a super-large wave flume. Marine Geology 391:98-107 https://doi.org/10.1016/.margeo.2017.07.020

Yoshii T, Tanaka S, Matsuyama M (2018) Tsunami inundation, sediment transport, and deposition process of tsunami deposits on coastal lowland inferred from the tsunami sand transport laboratory experiment (TSTLE). Marine Geology 400:107-118 https://doi.org/10.1016/j.margeo.2018.03.007

Yoshikawa S, Kanamatsu T, Goto K, Sakamoto I, Yagi M, Fujimaki M, Imura R, Nemoto K, Sakaguchi H (2015) Evidence for erosion and deposition by the 2011 Tohoku-oki tsunami on the nearshore shelf of Sendai Bay, Japan GeoMarine Letters, 35(4):315-328 https://link.springer.com/article/10.1007/s00367015-0409-3

Yoshikawa S, Sugawara D, Goto K, Sato A, Toshiya K, Sakaguchi H (2018) Numerical simulation for understanding of the offshore-directed sediment transport by 2011 Tohoku-oki tsunami at southern part of the Sendai Bay. Journal of Japan Society of Civil Engineers, Ser. B2 (Coastal Engineering) 74:I 337-I_342. (in Japanese with English abstract). https://doi.org/10.2208/kaigan. 74.I_337

\section{Publisher's Note}

Springer Nature remains neutral with regard to jurisdictional claims in published maps and institutional affiliations.

\section{Submit your manuscript to a SpringerOpen ${ }^{\circ}$ journal and benefit from:}

- Convenient online submission

- Rigorous peer review

- Open access: articles freely available online

- High visibility within the field

- Retaining the copyright to your article

Submit your next manuscript at $\boldsymbol{\nabla}$ springeropen.com 